\title{
PHOTOVOLTAICS: SOLAR ENERGY RESOURCES AND THE POSSIBILITY OF THEIR USE
}

\author{
FOTOWOLTAIKA: ZASOBY ENERGII SLONECZNEJ \\ I MOŻLIWOŚCI ICH WYKORZYSTANIA
}

\begin{abstract}
In this paper possibilities and limits of use of solar energy (like the best efficiencies of PV cells, world records and 'notable exceptions') were shown. Also some new ideas and concepts in photovoltaics (like new photovoltaic power plants or energy storage) were presented. Additionally authors try to predict development of solar power industry.
\end{abstract}

Keywords: photovoltaics, solar energy, development of solar power industry

\section{Introduction}

Today the world's energy needs are met mainly by exploitation of fossil fuels, whose resources are estimated globally at $1.2 \cdot 10^{14} \mathrm{MWh}$, including oil at $2.1 \cdot 10^{13} \mathrm{MWh}$. In contrast, fuel consumption in 2000 was approx. $6 \cdot 10^{11} \mathrm{MWh}$ [1]. This means that the situation is very serious, because according to various forecasts global growth in energy consumption of fossil fuels resources may be sufficient only for a few decades. Close perspective of their exhaustion and concerns about the state of the natural environment necessitated increased interest in renewable energy sources in the last decades of the twentieth century, and consequently led to a large increase in their applications. From 1990 to 2000, the amount of energy (heat and electricity) generated from solar energy has more than doubled. After signing the Kyoto Protocol in December 1997 the role of renewable energy sources is evident.

Currently in the world there is a change in energy priorities. New cleaner technologies have been adapted to local needs, they begin to attract the interest of investors and local authorities, slowly competing with monopolized and centralized energy sector. When comparing different energy options, economic costs gradually cease to be the decisive

\footnotetext{
${ }^{1}$ Division of Physicochemical Research, Faculty of Natural Sciences and Technology, Opole University, ul. kard. B. Kominka 6, 45-032 Opole, Poland, phone +48 7740160 42, fax +48 774016051 , email: maria.waclawek@uni.opole.pl

${ }^{2}$ Institute of Industrial Electrical Engineering, Faculty of Electrical Engineering, Czestochowa University of Technology, al. Armii Krajowej 17, 42-200 Częstochowa, Poland, email: zaremba@el.pcz.czest.pl

*Corresponding author: trodziewicz@wp.pl
} 
criterion. Increasingly count factors, which economic value is difficult to calculate directly, especially in the face of the possibility of further energy crises.

\section{Solar energy resources in the world}

Solar energy is an unlimited reservoir of renewable energy. The power of solar radiation emitted to space is $4 \cdot 10^{20} \mathrm{MW}$. The averaged value of the intensity of radiation reaching the Earth's upper atmosphere (the so-called solar constant) is as high as $1367 \mathrm{~W} / \mathrm{m}^{2}$ (WMO Commission Measurements and Methods of Observation, 8 session, Mexico City, 1981), which means that the Earth reaches $10^{18} \mathrm{kWh} /$ year. This energy is greater than the energy of all the identified fossil energy resources.

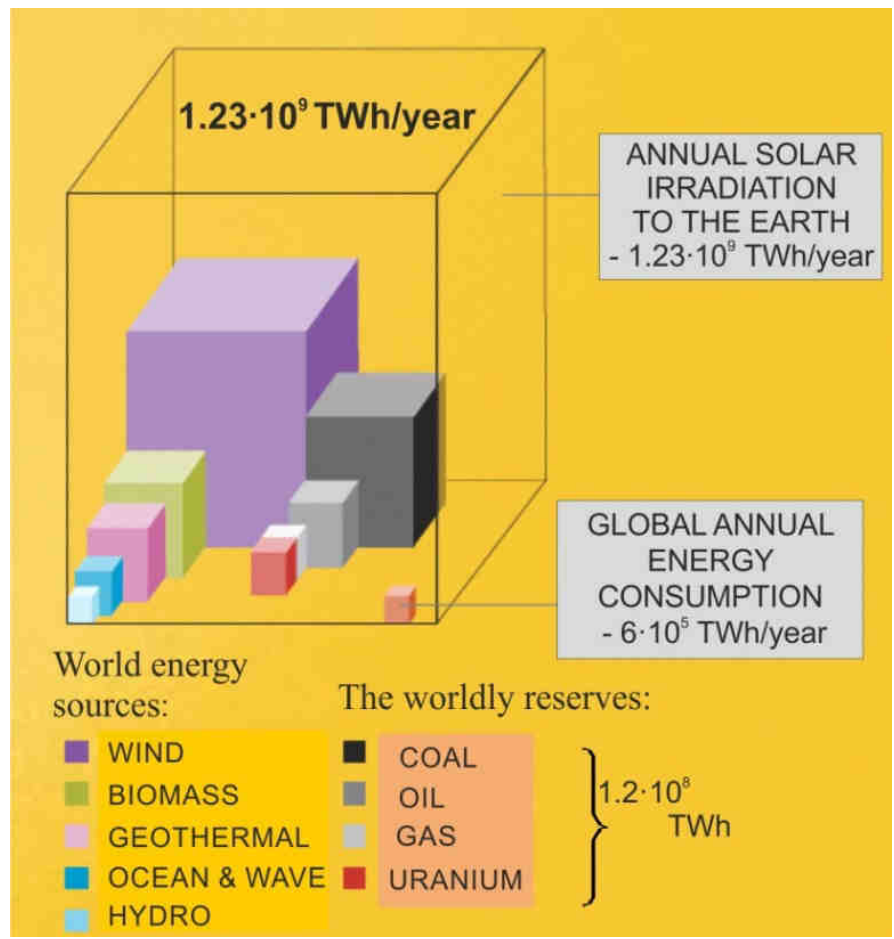

Fig. 1. Available energy resources (all known reserves - fossil fuels, yearly potential - renewable energy) [2]

As we can see in Figure 1, reserves of fossil fuels are limited and in comparison to energy consumption, they can be depleted in very short time (3-4 generations), so humankind should look for other energy sources, to cover demand. Comparing to the available renewable energy resources, we can see that these sources are much higher than our consumption. Even if we realize that efficiency of renewables is sometimes about $10 \%$, these sources have a much greater potential than our needs. So using renewable in future is the only chance to provide energy especially for developing countries.

It is estimated that the installation of photovoltaic power plants in the Sahara desert with the active surface of the photovoltaic modules (400 x 400) $\mathrm{km}^{2}$ (it is less than $1.75 \%$ 
of the surface of the desert) would satisfy completely today's global demand for electricity* (Fig. 2). Application of tracking systems and light concentrators can improve this result. A major problem now is to transfer this energy to customers, which share a large distance from the place of production. However, the problem of large energy losses during transmission can almost completely disappear once the wires of power grid are superconducting and cheap. Global research on superconductivity are developed very rapidly and probably on the positive results you will not have long to wait.

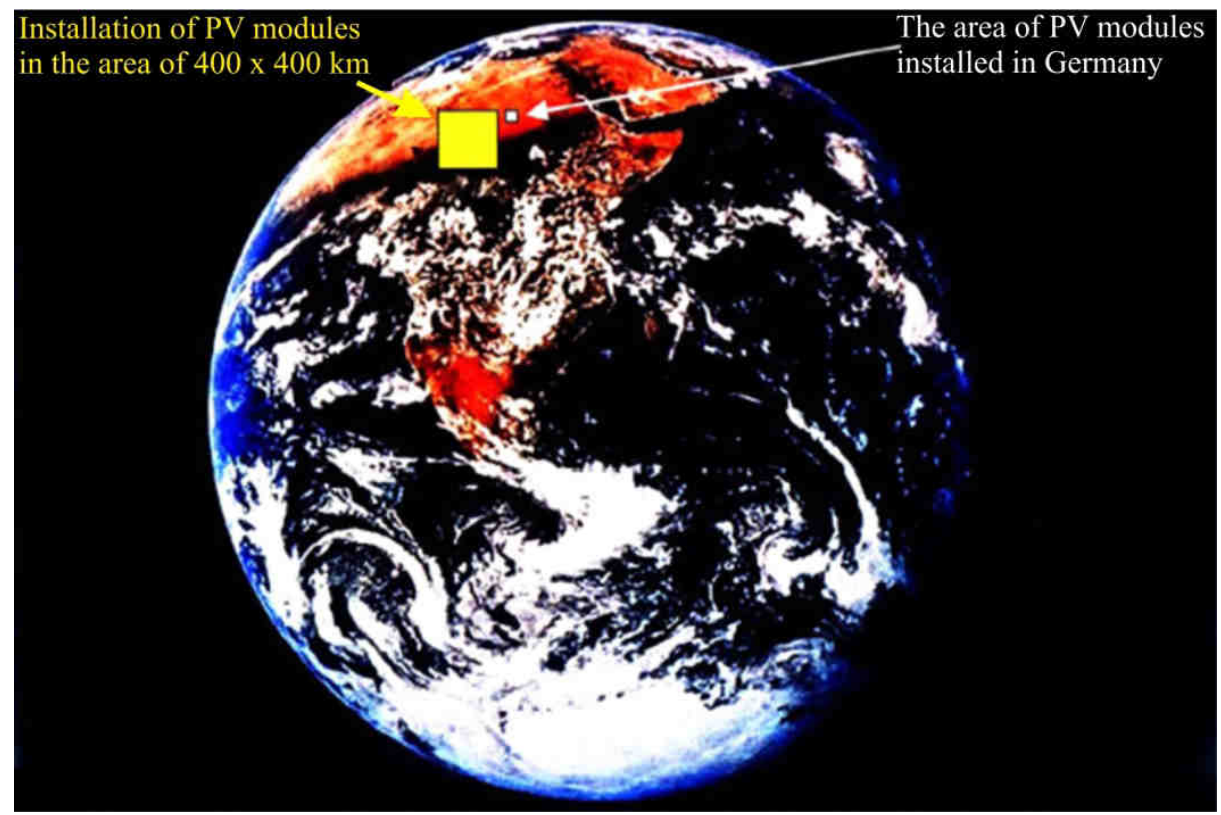

Fig. 2. Comparison of the area of PV systems in Germany with the surface of PV systems in the area of $(400 \times 400) \mathrm{km}^{2}$ which can secure the total electricity consumption of the World

\section{Local solar energy resources for the southern Poland}

Solar energy resources in Poland and other European countries are mainly related to the geographical location (mainly latitude of countries) and the prevailing local weather conditions. For many years, they are subject of testing and registration by number of meteorological and actinometric stations. These resources are characterized by:

- insolation, the number of hours of sunshine per year (or during the expected life of the solar system);

- irradiation, ie the flux of solar radiation reaching the horizontal/inclined surface;

- structure of the solar radiation, ie the individual components: direct radiation, diffused and reflected (at the level of the inclined surfaces) of the total radiation;

\footnotetext{
* These calculations were carried out with the following assumptions: 1) the annual value of irradiation of the Sahara is approx. 2.2 $\mathrm{MWh} /\left(\mathrm{m}^{2}\right.$ year); 2) the demand for electricity in the world is at $2 \cdot 10^{4} \mathrm{TWh}$ (ie the value of the energy produced in 2008); 3 ) the use of conventional PV modules with an efficiency $\eta_{\mathrm{STC}}=10 \%$ and assuming typical values of energy conversion for PV systems connected to the network $P R=0.75$.
} 
- distribution over time of solar radiation in annual, seasonal and daily cycles.

The possibility of using solar energy varies greatly depending on location. In Poland, the climatic conditions are determined by significant changes in the angle of incidence of solar radiation on an annual basis, and the clash of two fronts - Atlantic and Continental, resulting in huge differences in climatic conditions. Large clouds and rainfall in autumn and spring, cold air in winter, are the cause of very uneven distribution of radioactivity and its structure on an annual basis. About 80\% [3] of the total annual irradiation falls for seven months in spring and summer (April to October). The structure of the solar radiation in Poland is characterized by a high proportion of distributed component in the total irradiation. During the year, it amounts to over $50 \%$, and during the four months of winter (November-February) reaches maximum values varies between $65-73 \%$ [3].

\section{Distribution of the irradiation}

Table 1 summarizes the average monthly values of the energy of radiation on the horizontal plane in AGH-Krakow area for 2009 originating from: a) a global (the total), and b) a diffused component of solar radiation. However, histogram of the daily values of irradiation, occurring in 2009, in AGH Krakow area is shown in Figure 3.

Table 1

Summary of monthly values (in the plane of the horizon) of the solar radiation energy: total (global), diffused and diffused component content index, in AGH Krakow area in 2009 [4]

\begin{tabular}{|c|c|c|c|}
\hline Month & $\begin{array}{c}\text { Global irradiation } \boldsymbol{E}_{\mathbf{0}} \\
{\left[\mathbf{k W h} / \mathbf{m}^{\mathbf{2}}\right]}\end{array}$ & $\begin{array}{c}\text { Diffused irradiation } \boldsymbol{E}_{\boldsymbol{S}} \\
{\left[\mathbf{k W h} / \mathbf{m}^{\mathbf{2}}\right]}\end{array}$ & $\begin{array}{c}\boldsymbol{k}_{\mathbf{S / 0}} \\
{[-]}\end{array}$ \\
\hline January & 22.1 & 15.4 & 0.70 \\
\hline February & 33.3 & 27.6 & 0.83 \\
\hline March & 57 & 40.6 & 0.71 \\
\hline April & 157.8 & 52.9 & 0.33 \\
\hline May & 163.4 & 69.6 & 0.43 \\
\hline June & 137.6 & 72.8 & 0.53 \\
\hline July & 188.7 & 74.3 & 0.39 \\
\hline August & 146.1 & 57.3 & 0.39 \\
\hline September & 103.2 & 47.6 & 0.46 \\
\hline October & 41.9 & 29.0 & 0.69 \\
\hline November & 29.7 & 16.3 & 0.55 \\
\hline December & 13.3 & 10.4 & 0.78 \\
\hline 2009 & 1094.2 & 513.7 & 0.47 \\
\hline
\end{tabular}

The histogram shows that the test area was characterized by the presence of a large number of cloudy days with insolation not exceeding $800 \mathrm{Wh} / \mathrm{m}^{2}$, which accounted for more than $24.5 \%$ of the monitoring period. They are mostly a day MIMT (Medium Irradiation, High Temperature) or even LILT (Low Irradiation, Low Temperature) [5, 6] for the period of autumn and winter (from October to March). During the six months only $18 \%$ of the annual energy radiation (see Table 1), reaches the module. Then they are very difficult conditions for photovoltaic energy conversion, and energy needs increased (the need of heating, lighting for a long time because of the short days and frequent heavy overcast and reheating the water from the lower temperature).

In addition, during the monitoring period were $35.9 \%$ of cloudy days with irradiation in the range of 800 to $3200 \mathrm{Wh} / \mathrm{m}^{2}$. These are the days of the typical weather failures 
occurring in the entire period of spring and autumn. Then median ${ }^{*}$ exceeds $1.6 \mathrm{kWh} / \mathrm{m}^{2}$, in which typical modern PV inverter already operates with an efficiency of up to $98 \%$ of its maximum efficiency [7-9], and a typical PV system already exceeds $75 \%$ of its nominal performance [3]. To different category can be classified so-called sunny and very sunny days (like HIHT-High Irradiation, High Temperature), which are respectively 18.6 and $21 \%$ of the days monitored. They occur during the spring and summer, in which are the ideal conditions for the operation of photovoltaic systems. Since the number of these days largely depends the value of generated energy in the PV system [10].

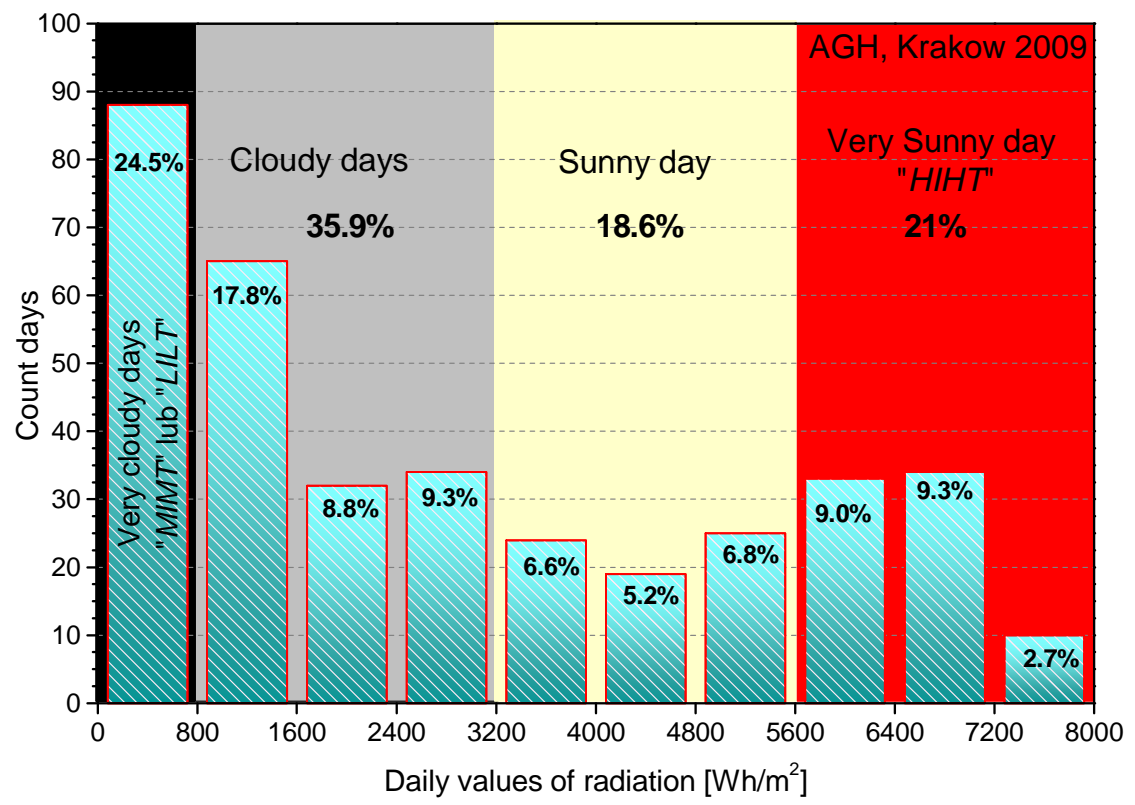

Fig. 3. Histogram of the daily values of irradiation, occurring in 2009, in AGH Krakow area [4]

\section{Distribution of temperature and intensity of solar radiation}

Figure 4a shows the distribution of average air temperatures in 2009 for the area of Krakow. One may notice the lack of symmetry of hourly temperature distribution. In summer days are characteristic cooler mornings and significant warming in the afternoon and evening hours.

However, Figure $4 \mathrm{~b}$ shows the distribution of intensity of solar radiation on the horizon surface at the testing site. Note the wide range of changes in both the intensity of the radiation, as well as the time of solar radiation. The data are the basis to determine the so-called insolation of area, ie determine the average number of hours of daily activity of the Sun in different months of the year, enough ${ }^{* *}$ to operate the PV system.

\footnotetext{
* The expected value of the distribution of insolation

** Typical photovoltaic inverter has a characteristic threshold of DC input power connected to the area of this work at maximum efficiency. For properly designed PV system that threshold inverter DC input power corresponds to value of solar radiation $\approx 200 \mathrm{~W} / \mathrm{m}^{2}$. Then a typical efficiency of the inverter is already above $95 \%$ of its maximum efficiency
} 

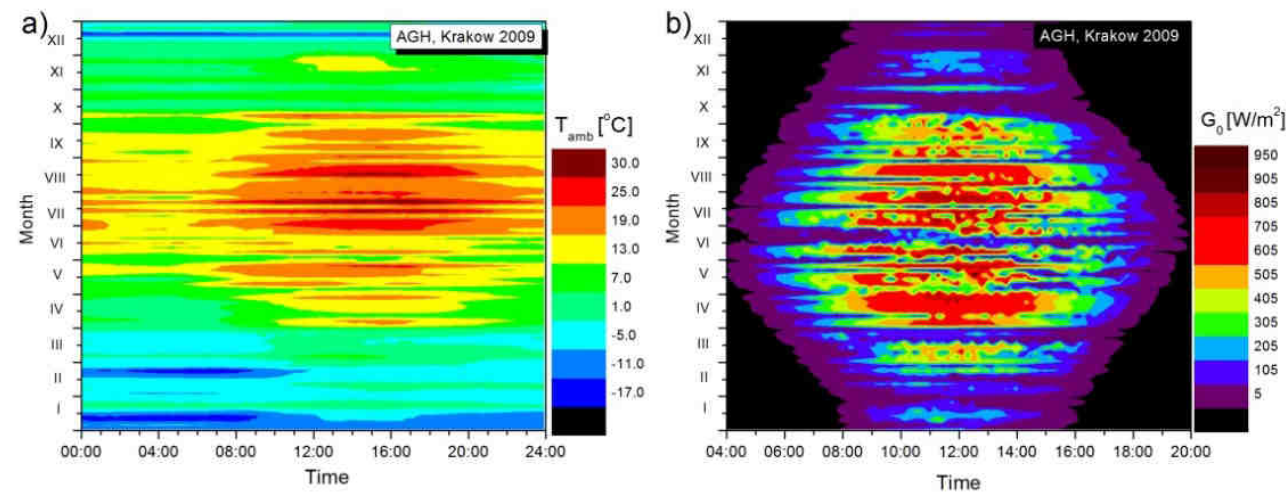

Fig. 4. Distribution of daily values of: a) air temperature and b) intensity of solar radiation occurring in the AGH in Krakow in 2009 [4]

\section{Distribution of values diffused component content index of solar radiation}

The relationship between the intensity of solar radiation incident on the earth's surface, and reaching into the upper atmosphere in the plane of the horizon is a measure of the transparency of the atmosphere and is determined as the clearness index $\left(k_{T m}\right)$. This index translates directly to the contents of a diffused component of the global solar radiation incident on the surface of horizon, known in the literature as diffused component content index $k_{S / 0}$ (see Figure 5).

For each day of month one could determine from integral values [11]:

- daily atmosphere clearness index $k_{T m}$ as:

$$
k_{T m}=\frac{E_{0}(0)}{E_{C}(0)}
$$

- daily diffuse component content index of solar radiation as:

$$
k_{S / 0}=\frac{E_{S}(0)}{E_{0}(0)}
$$

where: $E_{C}(0)$ - average daily value of insolation energy in specific month in higher layer of atmosphere in horizontal plane, $E_{0}(0)$ - daily value of insolation energy, $E_{S}(0)$ - daily value of insolation energy from diffuse component.

Similarly as in the case of daily values of indexes, temporary values of atmosphere clearness (transparency) and diffuse component content indexes could be computed. It is made by substitution in equations (1) and (2) daily energy values by temporary values of solar radiation intensity and then the equations take form, respectively:

$$
\begin{gathered}
k_{T m}(t)=\frac{G_{0}(t)}{G_{C}(0) / A M p(t)} \\
k_{S / 0}(t)=\frac{G_{S}(t)}{G_{0}(0)}
\end{gathered}
$$


Solar radiation intensity $G_{C}(0)$ in higher layers of atmosphere in plane of horizon for specified day in year is described $[10,12]$ by:

$$
\begin{gathered}
G_{C}(0)=E_{C}^{0} \cdot \varepsilon \\
\varepsilon=1+0.033 \cdot \cos \left(\frac{360 \cdot d n}{365}\right)
\end{gathered}
$$

where: $E_{C}^{0}$ - solar constant $\left(1367 \mathrm{~W} / \mathrm{m}^{2}\right), d n$ - number of day in year, ie January the $1^{\text {st }}=1$, February the $1^{\text {st }}=32$, etc. Parameter $A M p(t)$ in equations (3) and (4) is value of real mass of air given by Kaston and Young in 1989 in the form [13]:

$$
A M p(t)=\frac{p}{p_{0}} \cdot\left[\cos \Theta+0.50572 \cdot\left(96.079950^{\circ}-\Theta\right)^{-1.6364}\right]^{-1}
$$

Mutual connections of daily indexes defined according to (1) and (2) were shown in Figure 5a, while in Figure 5b was presented monthly values for Warszawa, Poland.

a)

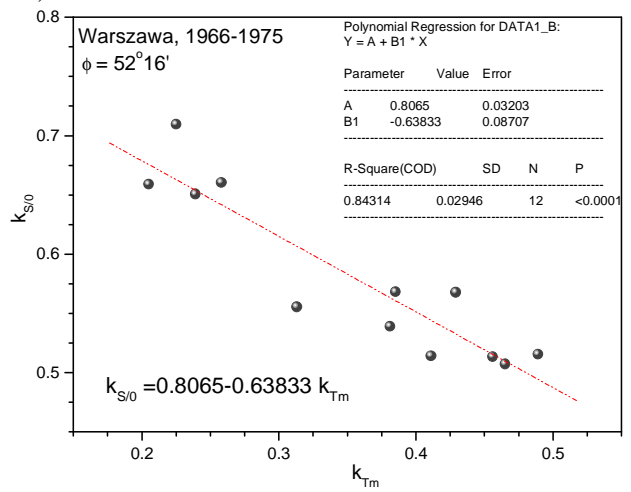

b)

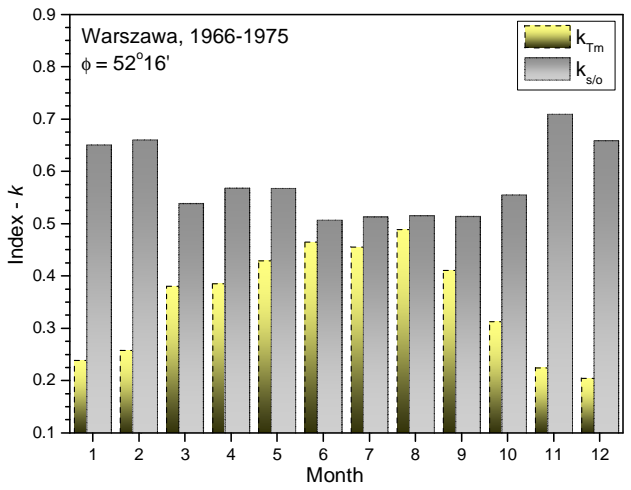

Fig. 5. Graphs: a) diffuse component content index $k_{S / 0}$ as a function of diffuse component content index of solar radiation $k_{T m}, \mathrm{~b}$ ) diffused component content and atmosphere clearness indexes for each month of the year. The graph is made on the basis of averaged data for the years 1966-1975, published in the European Solar Radiation Atlas for Warszawa [14]

Figures 6 a-i are examples of the daily value of the atmosphere clearness and diffused component content in the global solar radiation values occurring in Krakow for a few days with different values of daily irradiation.

Presented diffused component content and atmosphere clearness indexes are physically connected not only with solar radiation way through the Earth's atmosphere, which is dependent on the value of AM, but also on the chemical composition and the clouds.

Liu and Jordan have already shown [15] that, regardless of latitude, the global value of the intensity of solar radiation reaching the Earth's surface is directly dependent on this parameters. For this reason, these indexes can properly characterize the solar conditions for specified locations. It can also provide information about the average photon energy in the spectrum, and the structure of the solar spectrum (see Figure 7). 

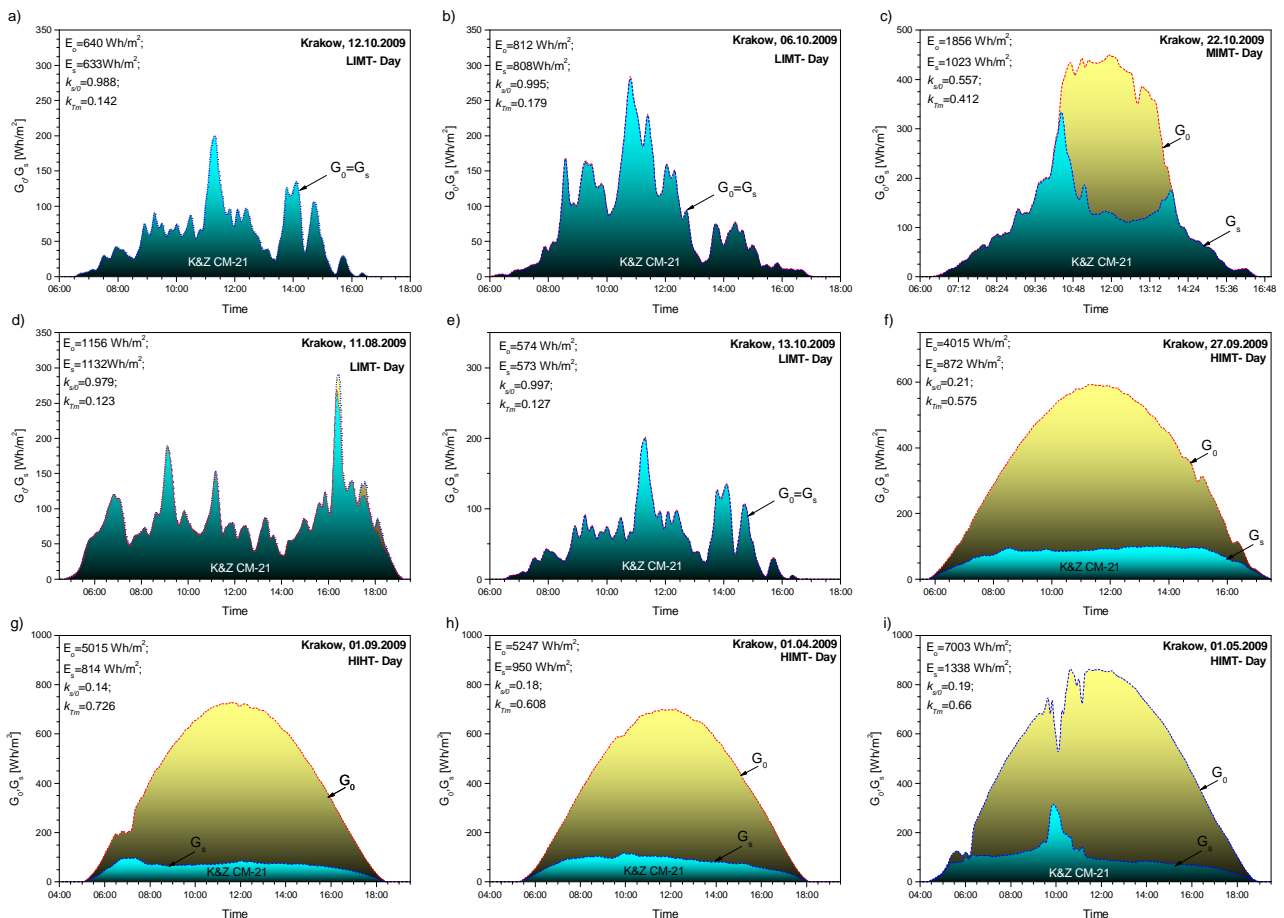

Fig. 6. Global solar radiation intensity and related to it indexes of atmosphere clearness and diffuse component content for days with different values of insolation. Investigations were carried out in Krakow, Poland for different days [4]

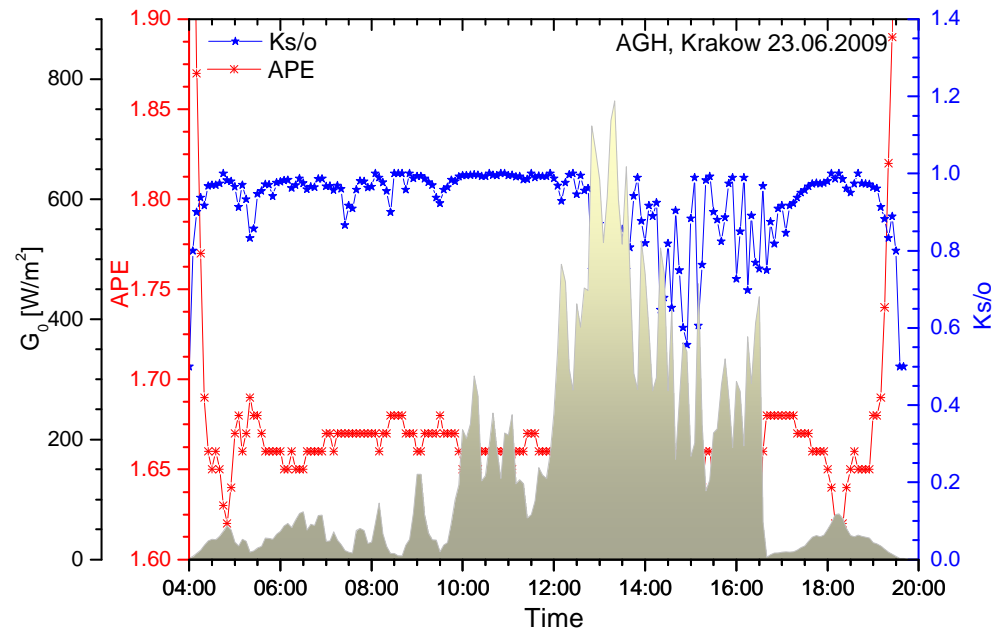

Fig. 7. Diffused component content index, average photon energy and global solar irradiance during cloudy day [4] 

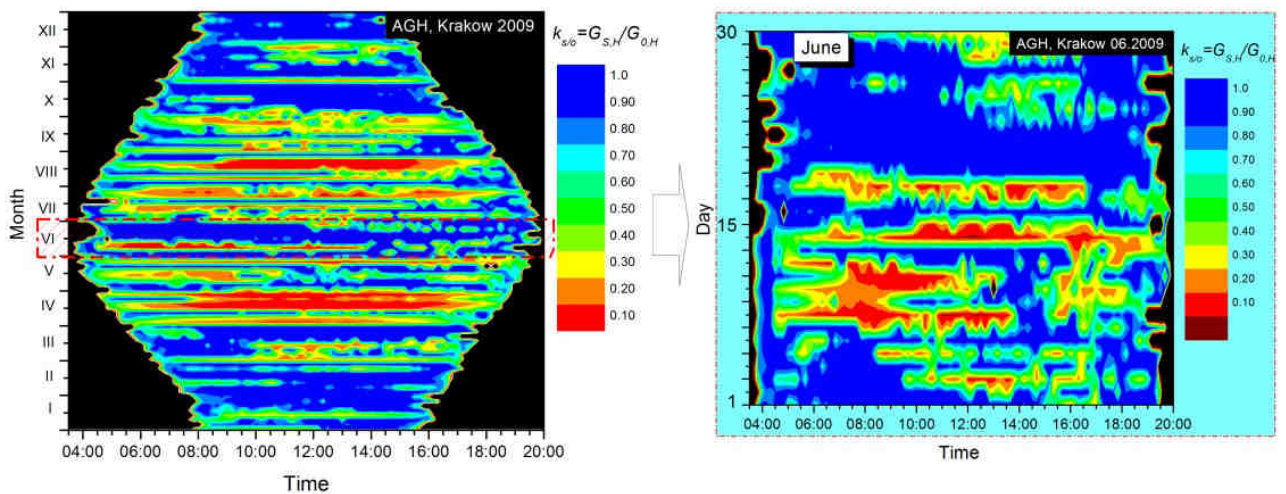

Fig. 8. Diffused component content index $k_{S / 0}$ of solar radiation for AGH Krakow area in 2009. In zoomed window (blue field) - temporary values of the index in June 2009 [4]

Diffused component content index $k_{S / 0}$ directly determines the level of cloud cover. It is very useful for a proper characterization of specified locations in order to select the optimal modules for climatic conditions. For example, in Figure 8 is shown the diffused component content index for the area of AGH Krakow 2009. In the enlarged graph (blue box) - are instantaneous values of index in June 2009.

\section{Distributions average values of photon energy and useful fraction of solar radiation}

The average photon energy value is determined by the measurement of the spectrum and is the quotient of the power and flux density in specified band recorded by the wide range receiver according to:

$$
A P E=\frac{\int_{0.3 \mu \mathrm{m}}^{1.7 \mu \mathrm{m}}\left[N_{p h}(\lambda) E_{p h}(\lambda)\right] d \lambda}{q \int_{0.3 \mu \mathrm{m}}^{1.7 \mu \mathrm{m}} N_{p h}(\lambda) d \lambda}
$$

where: $A P E$ - average energy of solar radiation photons, $q$ - electron charge, $N_{p h}(\lambda)$ - number of photons in sunlight in the wavelength $\lambda, E_{p h}(\lambda)$ - the energy of a photon in the wavelength $\lambda$.

$A P E$ of the standard spectrum evaluated from different spectral integration limits (own calculations)

\begin{tabular}{|c|c|c|}
\hline & $\begin{array}{c}\text { Measurement (integration) range } \\
{[\mathbf{n m}]}\end{array}$ & $\begin{array}{c}\boldsymbol{A P E} \\
{[\mathbf{e V}]}\end{array}$ \\
\hline 1 & $300-4000$ & 1.43 \\
\hline 2 & $300-2500$ & 1.48 \\
\hline 3 & $300-1700$ & 1.62 \\
\hline 4 & $300-1100$ & 1.86 \\
\hline
\end{tabular}

The method of the solar radiation spectrum analysis using the average photon energy has several advantages. One of them is occurring very strong correlation between the 
average photon energy (APE), a range of short-term spectral characteristics of solar radiation, which strongly influences the efficiency of photovoltaic cells. In addition, the assuming as a unit of $A P E[\mathrm{eV}]$, gives a full picture of the spectral matching of used absorber in PV cell/module to the solar spectrum. It should be noted that the APE value depends on the bandwidth integral of equation (8). This effect is shown in Table 2, which compares the obtained results of average photon energy of standard spectrum (STC, type of radiation $\mathrm{AM} 1.5 \mathrm{G})$, using a different bandwidth of measurement devices.
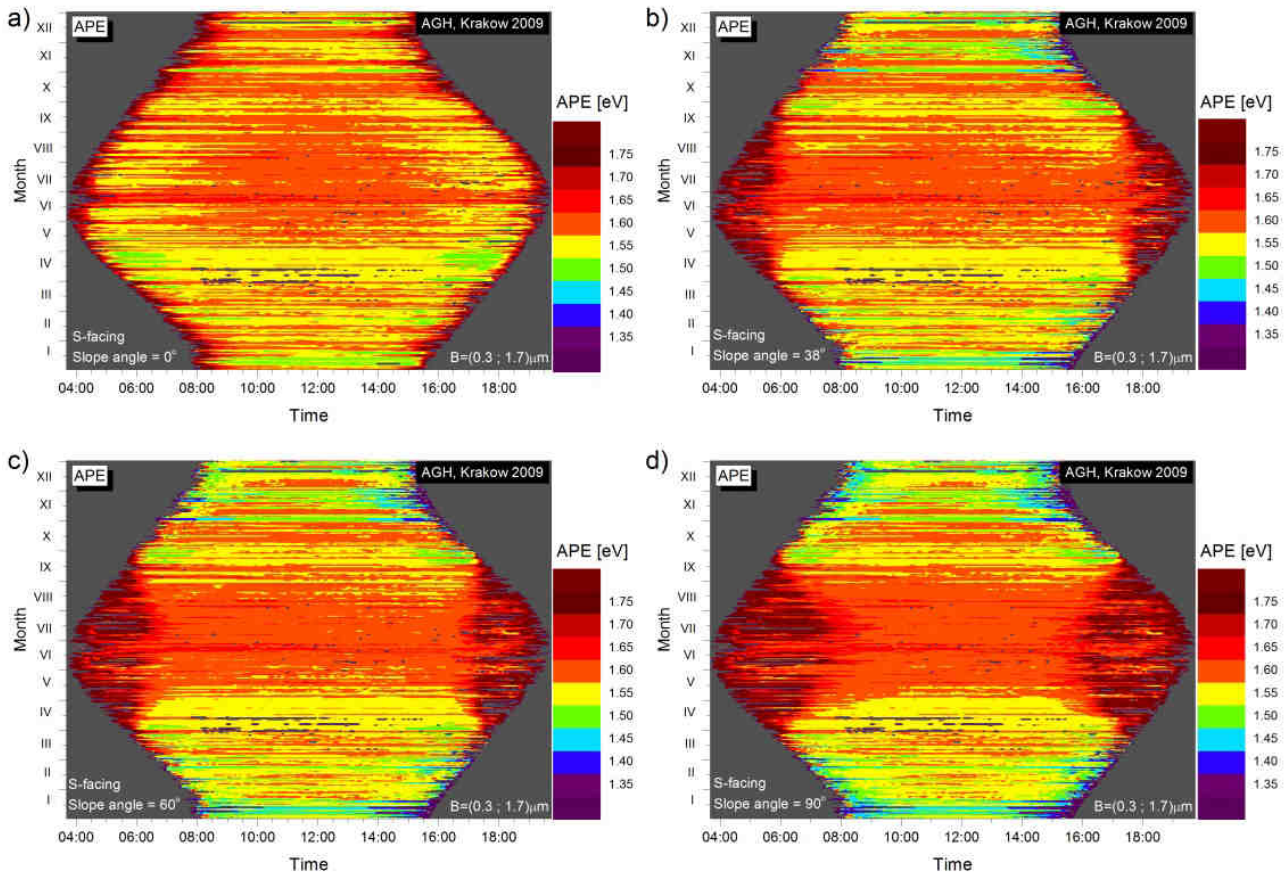

Fig. 9. The distribution of the average photon energy for: a) horizontal position, b) the optimum angle for the Krakow area $\left(38^{\circ}\right)$, c) typical for PV facades angle $60^{\circ}$, d) vertical position $\left(90^{\circ}\right)$. All planes have southern setting [4]

The most appropriate definition of $A P E$ would relate to the average photon energy obtained from the measurements using full range of the solar spectrum 300-4000 nm, because the result gives the true value of $A P E$. However, the measurement instruments in this range are very rare and unsuitable for use in long-term test cycles. Taking into account that the spectral range of solar radiation (distribution type AM1.5G) in the range from 300 to $2500 \mathrm{~nm}$ contains over $98 \%$ of its power so making measurements in this band is a very interesting, although there is also a very small number of units with this range. However, the measurements made in the wavelength range up to $1700 \mathrm{~nm}$ can be easily extended to $2500 \mathrm{~nm}$ with sufficient precision modelling - for example, method of measuring range extending from $300-1100 \mathrm{~nm}$ silicon sensor range spectroradiometer, up to $4000 \mathrm{~nm}$, has been recently developed by NREL (National Energy Renewable Laboratory - Golden, Colorado, USA) [16]. Unchallenged rule is that the most reliable measurement values are based purely on the measurements. Therefore, the measurement system used in 
the CREST (Centre for Energy Renewable Technology) measures the spectrum of radiation in the spectral range $300-1700 \mathrm{~nm}$, without the use of additional procedures, and the result is given indicating the width of the band.

For such assumptions, Figure 9 shows the distribution of the average photon energy for: a) horizontal position, b) the optimum angle for the Krakow area $\left(38^{\circ}\right)$ and c) typical for PV facades angle $60^{\circ}$, d) vertical position $\left(90^{\circ}\right)$. All planes have southern setting.

Useful fraction (UF) is called a power contained in the frequency band of the spectrum of solar radiation, limited by spectral sensitivity of the semiconductor absorber (eg: $\mathrm{c}-\mathrm{Si}, \mathrm{mc}-\mathrm{Si}, \mathrm{CIS}$, and $\mathrm{Si} \_\mathrm{SJ}-$ and-Si_TJ $)^{*}$ to the power of solar radiation recorded by broadband meter with bandwidth $\left(0.3 \mu \mathrm{m}, \lambda_{\text {cut }}\right)$ according to:

$$
U F=\frac{\int_{\lambda_{1}}^{\lambda_{2}} P(\lambda) d \lambda}{\int_{0.3 \mu m}^{\lambda c u t} P(\lambda) d \lambda}
$$

where: $\lambda_{\text {cut }}$ - limit wavelength measured by the instrument (adopted by default, as the $1700 \mathrm{~nm}),\left(\lambda_{1} ; \lambda_{2}\right)$ - spectral sensitivity range of cell, known as the wavelength range for which the normalized value of the cell spectral response is $S R_{\text {norm }} \geq 0.5$ (see Figure 10), $P(\lambda)$ - spectral power density of the radiation for the wavelength $\lambda$.

As with the determination of $A P E, U F$ value is dependent on the bandwidth of the measuring instrument integration.

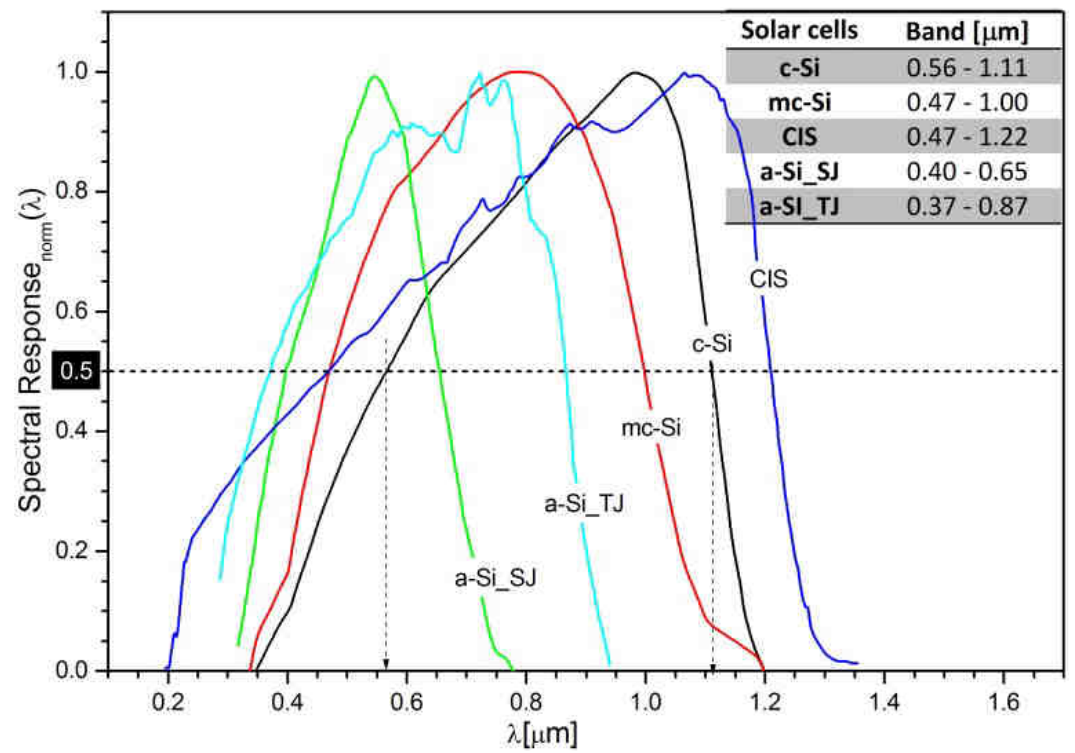

Fig. 10. Determination of conversion band for each cell absorber based on SR characteristics [4]

\footnotetext{
${ }^{*}$ c-Si - monocrystalline silicon; mc-Si - multicrystalline silicon; CIS - cell with CuInSe $\mathrm{C}_{2}$ absorber; a-Si SJ - single junction cell made of amorphous silicon; a-Si TJ - triple junction cell made of amorphous silicon
} 

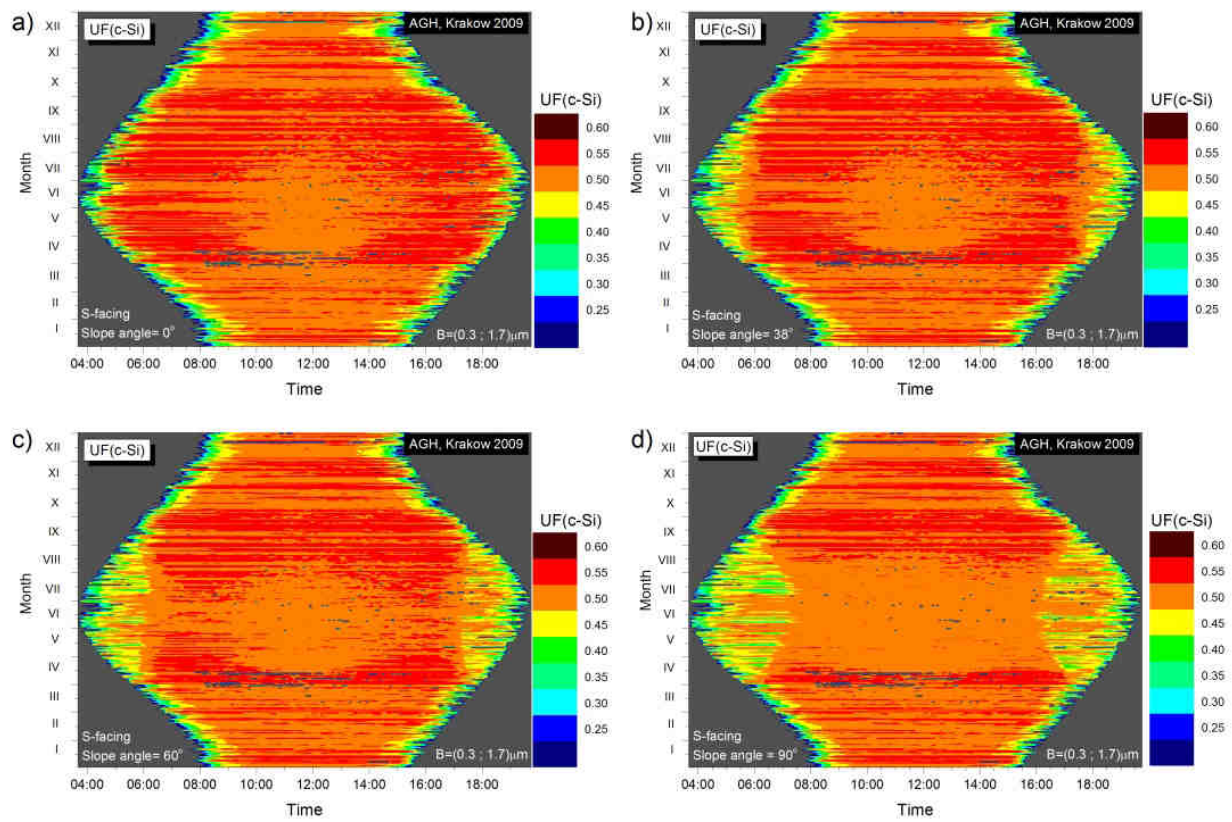

Fig. 11. The distribution of the useful fraction for solar cells/modules made of c-Si for: a) horizontal position, b) the optimum angle for the Krakow area $\left(38^{\circ}\right)$, c) angle $60^{\circ}$, d) vertical position. The meteorological data are from AGH Krakow area collected in 2009 [4]
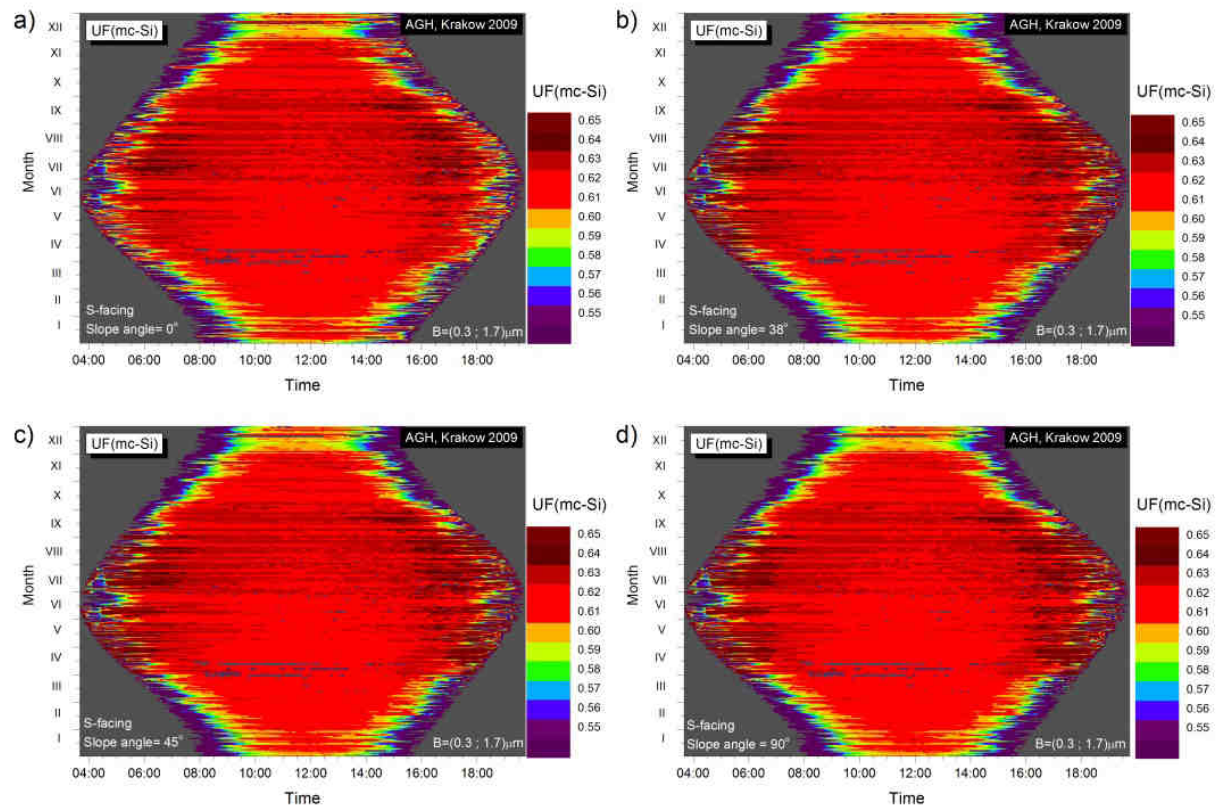

Fig. 12. The distribution of the useful fraction for solar cells/modules made of mc-Si for: a) horizontal position, b) the optimum angle for the Krakow area $\left(38^{\circ}\right)$, c) angle $60^{\circ}$, d) vertical position. The meteorological data are from AGH Krakow area collected in 2009 [4] 

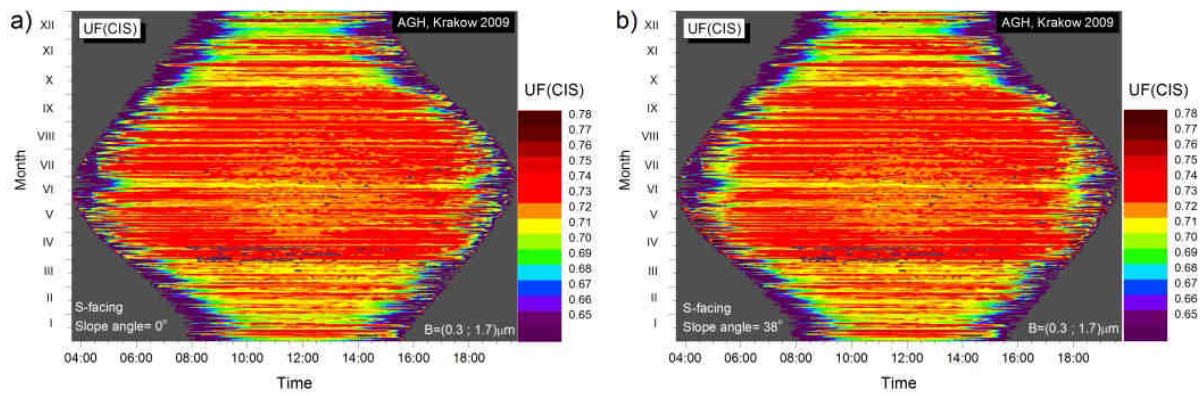

c)

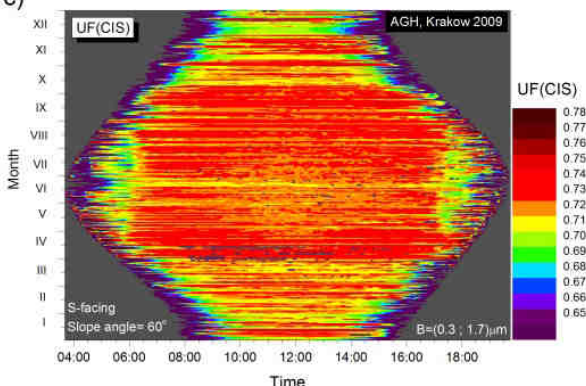

d)

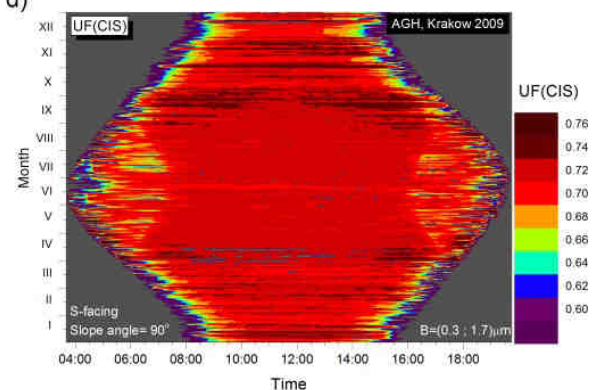

Fig. 13. The distribution of the useful fraction for solar cells/modules made of CIS for: a) horizontal position, b) the optimum angle for the Krakow area $\left(38^{\circ}\right)$, c) angle $60^{\circ}$, d) vertical position. The meteorological data are from AGH Krakow area collected in 2009 [4]
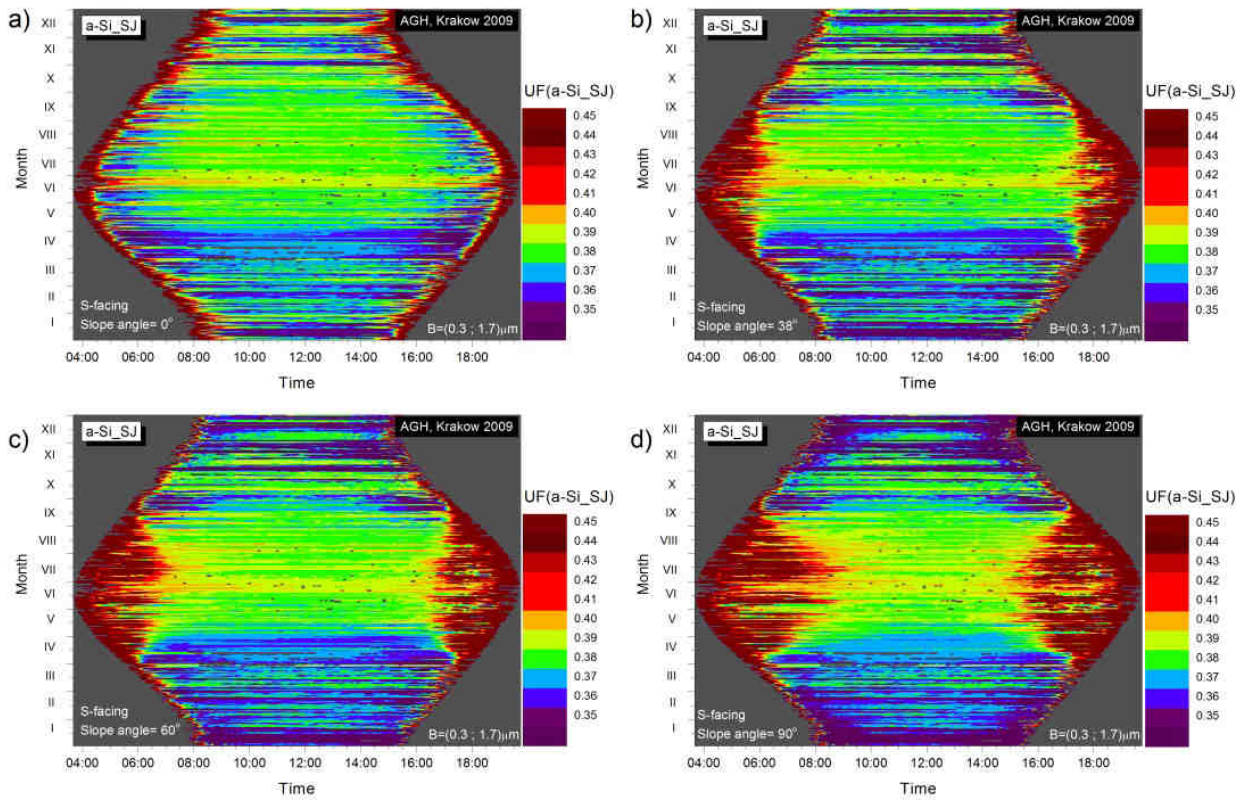

Fig. 14. The distribution of the useful fraction for solar cells/modules made of a-Si_SJ for: a) horizontal position, b) the optimum angle for the Krakow area $\left(38^{\circ}\right)$, c) angle $60^{\circ}$, d) vertical position. The meteorological data are from AGH Krakow area collected in 2009 [4] 

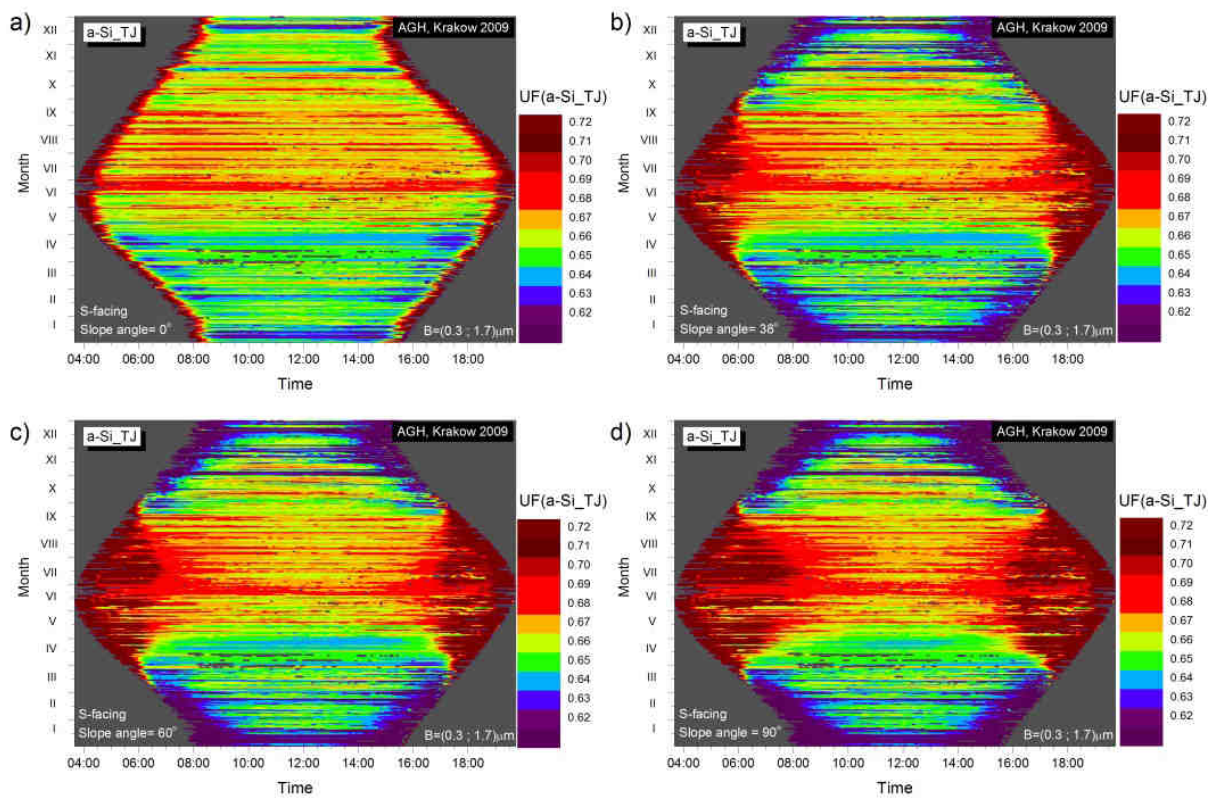

Fig. 15. The distribution of the useful fraction for solar cells/modules made of a-Si_TJ for: a) horizontal position, b) the optimum angle for the Krakow area $\left(38^{\circ}\right)$, c) angle $60^{\circ}$, d) vertical position. The meteorological data are from AGH Krakow area collected in 2009 [4]

Useful fractions are parameters dedicated for the type of PV cell/module. It is characterizing the spectrum of solar radiation, providing a direct information about the content of useful part in the spectrum involved in the conversion in that type of photovoltaic cell/module. It does not contain information about the impact of spectrum to other cells with different spectral sensitivity range, and does not indicate present (in the measurement) solar radiation intensity or the daily value of radiation energy.

Figures 11-15 show the distribution of the useful fraction for different types of solar cells/modules for: a) horizontal position, b) the optimum angle for the Krakow area $\left(38^{\circ}\right)$, c) angle $60^{\circ}$, d) vertical position. The meteorological data are from AGH Krakow area collected in 2009. Particular attention should be paid to:

- $\quad$ range of fraction values obtained for each cell;

- $\quad$ embodied phenomenon of seasonal distribution of UF - emphasizing with the angle of the modules exposure;

- occurring phenomenon a very good spectral fit for amorphous silicon single- and multi-junction during sunrise and sunset.

It should be noted that the same parameter $U F$ did not inform you of occurring irradiance or intensity of solar radiation in any given time. This means that it does not indicate how much energy produce the module for a certain period of time. It only present fitting of distribution of the solar radiation spectrum to spectral sensitivity of the cells, which directly translates into the derived values of efficiency, open circuit voltage and the Fill Factor $(F F)$. On the other hand, the impact of $U F$ on parameters such as short-circuit current $I_{S C}$ and the maximum power $P_{m}$ can be observed only in reference to the value of solar radiation. 

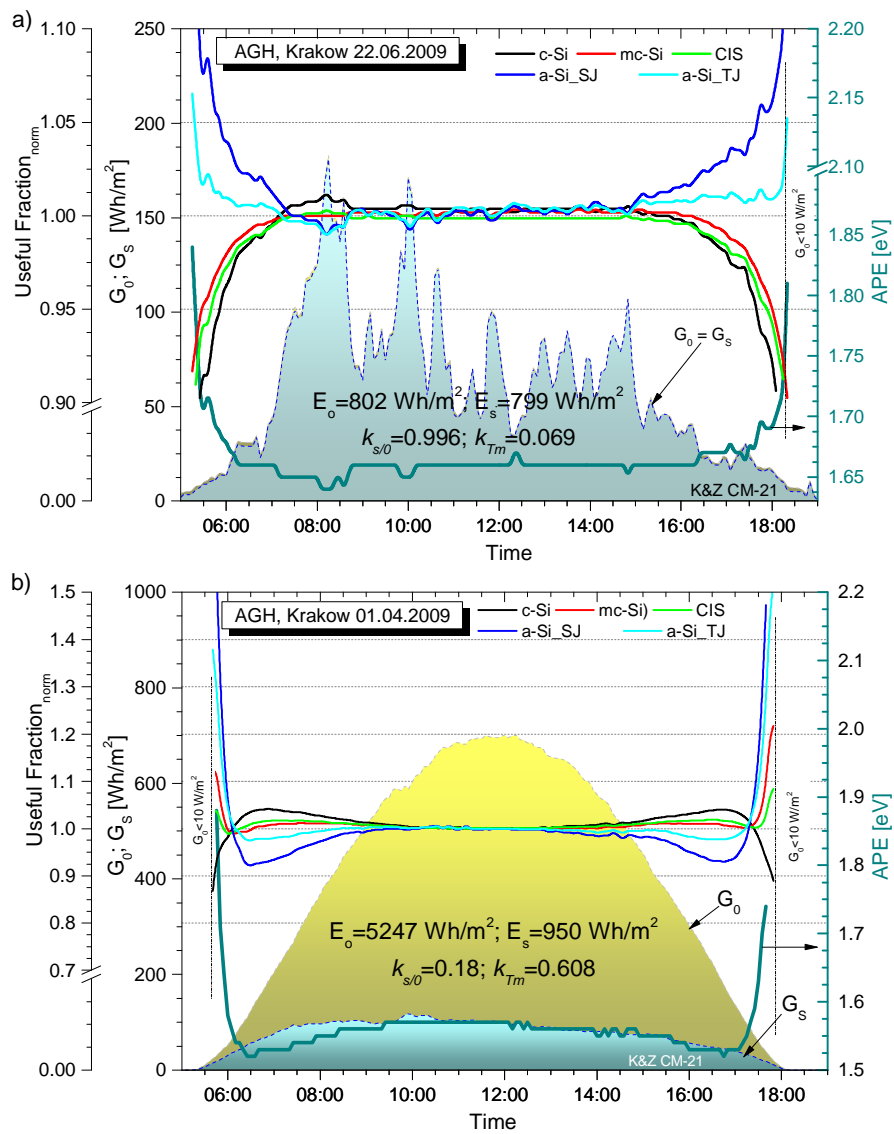

Fig. 16. Changes in the average photon energy of the solar radiation spectrum and the normalized values of the useful fraction for basic types of solar cells/PV modules, during: a) a cloudy summer day, and b) sunny spring day. Thick green line shows the course of APE during the day. The study was performed in the AGH Krakow area in 2009 [4]

Figure 16 shows changes in the average photon energy of the solar radiation spectrum and the normalized values of the useful fraction for basic types of solar cells / PV modules, during: a) a cloudy summer day, and b) sunny spring day. Thick green line shows the course of $A P E$ during the day. The study was performed in the AGH Krakow area in 2009.

\section{Photovoltaics: possibilities and limits of use - today and future}

\section{The latest efficiency of PV cells and modules}

For many years there has been competition between manufacturers and laboratories producing PV cells to establish a world record in efficiency of light conversion - Figure 17.

In April 2013 Fraunhofer Laboratory (FhG-ISE) confirmed that monolithic multijunction cell (InGaP/GaAs/InGaAs) made by Sharp, acquire world record (WR) in efficiency - 44.4\% [17, 18]. In September, 2014 world record efficiency of PV cells was 
$45.7 \%$ for the concentration of the light $(234 \mathrm{x})$ [17, 19], while in November 2014 it reached $46 \%$ for concentration of light $(508 \mathrm{x})[17,20]$. Until 27 April 2015, ie to carry out the above-mentioned analysis it was a world record for efficiency of established for monolithic multijunction cells designed to work with concentrated solar radiation [18, 20].

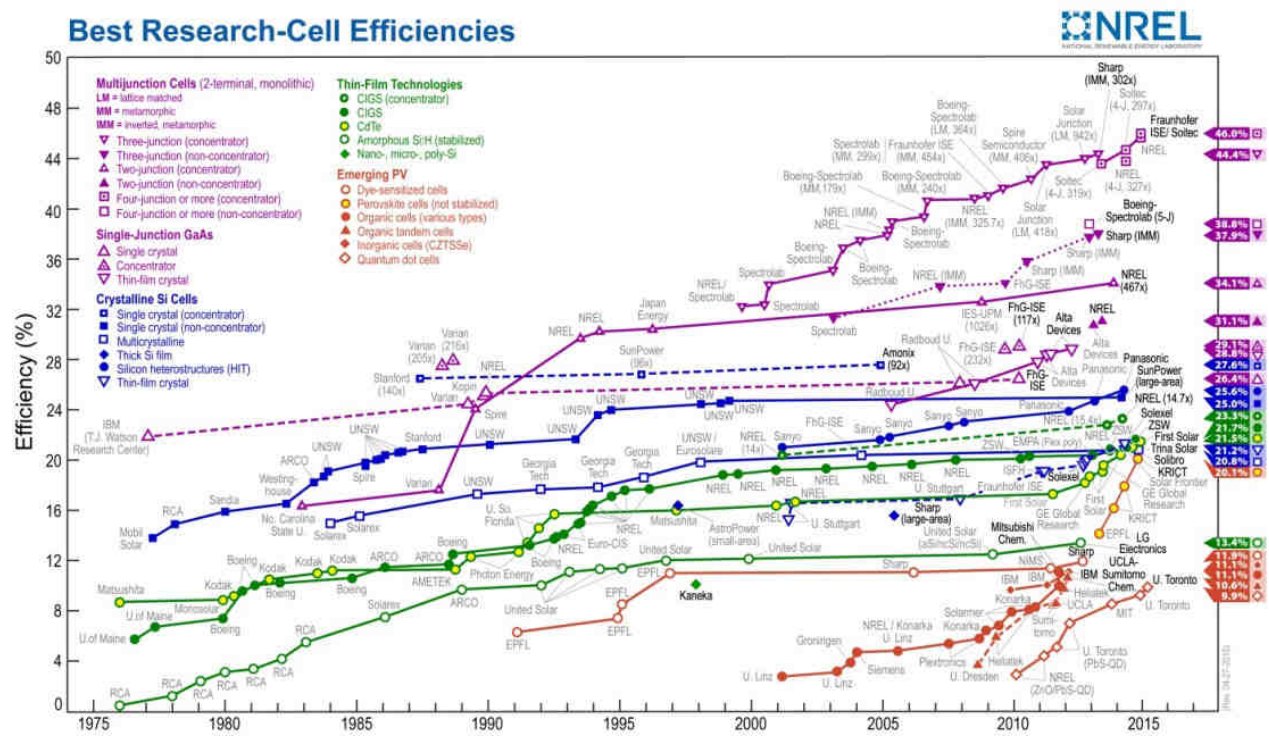

Fig. 17. Increase of PV cells efficiency according to National Renewable Energy Laboratory (27.04.2015). Legend: first part in bracket type of cell, second - concentration of sunlight, for example (4J, 297x) 4-junction cell working with concentrator of 297 Suns (5-J - five-junction, 4-J - four-junction, LM - lattice matched, MM - metamorphic, IMM - inverted, metamorphic) [17]

Confirmed terrestrial cell and submodule efficiencies measured under the global AM1.5 spectrum $\left(1000 \mathrm{~W} / \mathrm{m}^{2}\right)$ at $25^{\circ} \mathrm{C}$ (IEC 60904-3: 2008, ASTM G-173-03 global) [18, 20]

\begin{tabular}{|c|c|c|c|c|c|c|c|}
\hline Classification $^{1)}$ & $\begin{array}{c}E f f \\
{[\%]}\end{array}$ & $\begin{array}{l}S^{2)} \\
{\left[\mathrm{cm}^{2}\right]}\end{array}$ & $\begin{array}{l}\text { Voc } \\
{[V]}\end{array}$ & $\begin{array}{c}J s c \\
{\left[\mathbf{m A} / \mathbf{c m}^{2}\right]}\end{array}$ & $\begin{array}{l}F F \\
\%]\end{array}$ & $\begin{array}{l}\text { Test centre }^{3)} \\
\text { (data) }\end{array}$ & Description $^{3)}$ \\
\hline \multicolumn{8}{|c|}{ Silicon } \\
\hline $\mathrm{Si}$ (crystalline) & $\begin{array}{r}25.6 \\
\pm 0.5\end{array}$ & $\begin{array}{l}143.7 \\
\text { (da) }\end{array}$ & 0.740 & 41.8 & 82.7 & AIST (2/14) & $\begin{array}{l}\text { Panasonic HIT, } \\
\text { rear-junction }\end{array}$ \\
\hline Si (multicrystalline) & $\begin{array}{l}20.4 \\
\pm 0.5\end{array}$ & $\begin{array}{c}1.002 \\
\text { (ap) }\end{array}$ & 0.664 & 38.0 & 80.9 & NREL (5/04) & FhG-ISE \\
\hline Si (multicrystalline) & $\begin{array}{l}20.8 \\
\pm 0.6\end{array}$ & $\begin{array}{c}243.9 \\
\text { (ap) }\end{array}$ & 0.6626 & 39.03 & 80.3 & $\begin{array}{c}\text { FhG-ISE } \\
(11 / 14)\end{array}$ & Trina Solar \\
\hline $\mathrm{Si}$ (thin film transfer) & $\begin{array}{l}20.1 \\
\pm 0.4\end{array}$ & $\begin{array}{c}242.6 \\
\text { (ap) }\end{array}$ & 0.682 & 38.14 & 77.4 & NREL (10/12) & Solexel (43 $\mu \mathrm{m}$ thick) \\
\hline $\mathrm{Si}$ (thin film transfer) & $\begin{array}{l}21.2 \\
\pm 0.4 \\
\end{array}$ & $\begin{array}{c}239.7 \\
\text { (ap) }\end{array}$ & 0.687 & 38.50 & 80.3 & NREL (4/14) & Solexel (35 $\mu \mathrm{m}$ thick) \\
\hline \multicolumn{8}{|c|}{ III-V Cells } \\
\hline GaAs (thin film) & $\begin{array}{r}28.8 \\
\pm 0.9 \\
\end{array}$ & $\begin{array}{c}0.9927 \\
\text { (ap) }\end{array}$ & 1.122 & 29.68 & 86.5 & NREL (5/12) & Alta Devices \\
\hline GaAs (multicrystalline & $\begin{array}{l}18.4 \\
\pm 0.5\end{array}$ & $\begin{array}{c}4.011 \\
(\mathrm{t})\end{array}$ & 0.994 & 23.2 & 79.7 & NREL (11/95) & RTI, Ge substrate \\
\hline
\end{tabular}




\begin{tabular}{|c|c|c|c|c|c|c|c|}
\hline \multirow{2}{*}{ Classification $^{1)}$} & $E f f$ & $S^{2)}$ & Voc & Jsc & $F F$ & \multirow{2}{*}{$\begin{array}{c}\text { Test centre }^{3 \text { ) }} \\
\text { (data) }\end{array}$} & \multirow{2}{*}{ Description $^{3)}$} \\
\hline & {$[\%]$} & {$\left[\mathrm{cm}^{2}\right]$} & {$[\mathbf{V}]$} & {$\left[\mathrm{mA} / \mathrm{cm}^{2}\right]$} & {$[\%]$} & & \\
\hline InP (crystalline) & $\begin{array}{l}22.1 \\
\pm 0.7\end{array}$ & $\begin{array}{l}4.02 \\
(\mathrm{t})\end{array}$ & 0.878 & 29.5 & 85.4 & NREL (4/90) & Spire, epitaxial \\
\hline \multicolumn{8}{|c|}{ Thin film chalcogenide } \\
\hline CIGS (cell) & $\begin{array}{l}20.5 \\
\pm 0.6\end{array}$ & $\begin{array}{l}\mathbf{0 . 9 8 8 2} \\
\text { (ap) }\end{array}$ & 0.752 & 35.3 & 77.2 & NREL (3/14) & Solibro, on glass \\
\hline CIGS (minimodule) & $\begin{array}{l}18.7 \\
\pm 0.6\end{array}$ & $\begin{array}{c}15.892 \\
\text { (da) }\end{array}$ & 0.701 & 35.29 & 75.6 & $\begin{array}{c}\text { FhG-ISE } \\
(9 / 13)\end{array}$ & $\begin{array}{l}\text { Solibro, four serial } \\
\text { cells }\end{array}$ \\
\hline CdTe (cell) & $\begin{array}{l}19.6 \\
\pm 0.4\end{array}$ & $\begin{array}{l}1.0055 \\
\text { (ap) }\end{array}$ & 0.8573 & 28.59 & 80.0 & $\begin{array}{l}\text { Newport } \\
(6 / 13)\end{array}$ & GE Global Research \\
\hline CdTe (cell) & $\begin{array}{l}21.0 \\
\pm 0.4\end{array}$ & $\begin{array}{c}1.0623 \\
\text { (ap) }\end{array}$ & 0.8759 & 30.25 & 79.4 & $\begin{array}{c}\text { Newport } \\
(8 / 14)\end{array}$ & First Solar, on glass \\
\hline \multicolumn{8}{|c|}{ Amorphous/microcrystalline Si } \\
\hline $\mathrm{Si}$ (amorphous) & $\begin{array}{l}10.1 \\
\pm 0.3\end{array}$ & $\begin{array}{c}1.036 \\
\text { (ap) }\end{array}$ & 0.886 & 16.75 & 67.8 & NREL (7/09) & $\begin{array}{l}\text { Oerlikon Solar Lab, } \\
\text { Neuchatel }\end{array}$ \\
\hline Si (amorphous) & $\begin{array}{l}10.2 \\
\pm 0.3\end{array}$ & $\begin{array}{l}1.001 \\
\text { (ap) }\end{array}$ & 0.896 & 16.36 & 69.8 & AIST (7/14) & AIST \\
\hline Si (microcrystalline) & $\begin{array}{l}11.0 \\
\pm 0.3\end{array}$ & $\begin{array}{l}1.045 \\
\text { (da) }\end{array}$ & 0.542 & 27.44 & 73.8 & AIST (1/14) & AIST \\
\hline Si (microcrystalline) & $\begin{array}{l}11.4 \\
\pm 0.3\end{array}$ & $\begin{array}{c}1.046 \\
\text { (da) }\end{array}$ & 0.535 & 29.07 & 73.1 & AIST (7/14) & AIST \\
\hline \multicolumn{8}{|c|}{ Dye sensitised } \\
\hline Dye sensitised & $\begin{array}{l}11.9 \\
\pm 0.4\end{array}$ & $\begin{array}{l}1.005 \\
\text { (da) }\end{array}$ & 0.744 & 22.47 & 71.2 & AIST (9/12) & Sharp \\
\hline $\begin{array}{l}\text { Dye sensitised } \\
\text { (minimodule) }\end{array}$ & $\begin{array}{l}29.9 \\
\pm 0.4\end{array}$ & $\begin{array}{c}17.11 \\
\text { (ap) }\end{array}$ & 0.719 & 19.4 & 71.4 & AIST (8/10) & $\begin{array}{l}\text { Sony, eight parallel } \\
\text { cells }\end{array}$ \\
\hline $\begin{array}{l}\text { Dye sensitised } \\
\text { (minimodule) }\end{array}$ & $\begin{array}{l}10.0 \\
\pm 0.4\end{array}$ & $\begin{array}{c}24.19 \\
\text { (da) }\end{array}$ & 0.718 & 20.46 & 67.7 & AIST (6/14) & $\begin{array}{c}\text { Fujikura/Tokyo } \\
\text { U. Science }\end{array}$ \\
\hline Dye (submodule) & $\begin{array}{c}8.8 \\
\pm 0.3 \\
\end{array}$ & $\begin{array}{l}398.8 \\
\text { (da) }\end{array}$ & 0.697 & 18.42 & 68.7 & AIST (9/12) & Sharp (26 serial cells) \\
\hline \multicolumn{8}{|c|}{ Organic } \\
\hline Organic thin film & $\begin{array}{l}10.7 \\
\pm 0.3 \\
\end{array}$ & $\begin{array}{l}1.013 \\
\text { (da) }\end{array}$ & 0.872 & 17.75 & 68.9 & $\operatorname{AIST}(10 / 12)$ & $\begin{array}{l}\text { Mitsubishi Chemical } \\
(4.4 \times 23.0 \mathrm{~mm})\end{array}$ \\
\hline Organic thin film & $\begin{array}{l}11.0 \\
\pm 0.3 \\
\end{array}$ & $\begin{array}{c}0.993 \\
\text { (da) }\end{array}$ & 0.793 & 19.40 & 71.4 & AIST (9/14) & Toshiba \\
\hline Organic (minimodule) & $\begin{array}{c}9.1 \\
\pm 0.3 \\
\end{array}$ & $\begin{array}{c}25.04 \\
(\mathrm{da})\end{array}$ & 0.794 & 17.06 & 67.5 & AIST (2/14) & $\begin{array}{c}\text { Toshiba } \\
\text { (four series cells) }\end{array}$ \\
\hline $\begin{array}{c}\text { Organic } \\
\text { (minimodule) }\end{array}$ & $\begin{array}{c}9.5 \\
\pm 0.3\end{array}$ & $\begin{array}{c}25.05 \\
\text { (da) }\end{array}$ & 0.789 & 17.01 & 70.9 & AIST (8/14) & $\begin{array}{c}\text { Toshiba } \\
\text { (four series cells) }\end{array}$ \\
\hline Organic (submodule) & $\begin{array}{c}6.8 \\
\pm 0.2 \\
\end{array}$ & $\begin{array}{c}395.9 \\
\text { (da) }\end{array}$ & 0.798 & 13.50 & 62.8 & AIST (10/12) & $\begin{array}{c}\text { Toshiba } \\
(15 \text { series cells }) \\
\end{array}$ \\
\hline \multicolumn{8}{|c|}{ Multijunction devices } \\
\hline $\mathrm{InGaP} / \mathrm{GaAs} / \mathrm{InGaAs}$ & $\begin{array}{l}37.9 \\
\pm 1.2\end{array}$ & $\begin{array}{l}1.047 \\
\text { (ap) }\end{array}$ & 3.065 & 14.27 & 86.7 & $\operatorname{AIST}(2 / 13)$ & Sharp \\
\hline $\begin{array}{l}\text { a-Si/nc-Si/nc-Si } \\
\text { (thin film) }\end{array}$ & $\begin{array}{r}13.4 \\
\pm 0.4 \\
\end{array}$ & $\begin{array}{c}1.006 \\
\text { (ap) }\end{array}$ & 1.963 & 9.52 & 71.9 & NREL (7/12) & LG Electronics \\
\hline $\begin{array}{c}\mathrm{a}-\mathrm{Si} / \mathrm{nc}-\mathrm{Si} \\
\text { (thin film cell) }\end{array}$ & $\begin{array}{l}12.3 \\
\pm 0.3\end{array}$ & $\begin{array}{l}0.962 \\
\text { (ap) }\end{array}$ & 1.365 & 12.93 & 69.4 & AIST (7/11) & Kaneka \\
\hline $\begin{array}{c}\text { a-Si/nc-Si } \\
\text { (thin film cell) }\end{array}$ & $\begin{array}{l}12.7 \\
\pm 0.4\end{array}$ & $\begin{array}{c}1.000 \\
(\text { da })\end{array}$ & 1.342 & 13.45 & 70.2 & AIST (10/14) & AIST \\
\hline $\begin{array}{c}\mathrm{a}-\mathrm{Si} / \mathrm{nc}-\mathrm{Si} \\
\text { (thin film minimodule) }\end{array}$ & $\begin{array}{l}11.8 \\
\pm 0.6\end{array}$ & $\begin{array}{l}40.26 \\
\text { (ap) }\end{array}$ & 1.428 & 12.27 & 67.5 & $\begin{array}{c}\text { FhG-ISE } \\
(4 / 14)\end{array}$ & $\begin{array}{l}\text { TEL Solar, Trubbach } \\
\text { Labs (10 serial cells) }\end{array}$ \\
\hline
\end{tabular}

1) CIGS - CuInGaSe 2 ; a-Si - amorphous silicon/hydrogen alloy; nc-Si, nanocrystalline or microcrystalline silicon

2) ap - aperture area, $\mathrm{t}$ - total area, da - designated illumination area

3) FhG-ISE - Fraunhofer Institut für Solare Energiesysteme; AIST - Japanese National Institute of Advanced Industrial Science and Technology 
Confirmed terrestrial module efficiencies measured under the global AM1.5 spectrum $\left(1000 \mathrm{~W} / \mathrm{m}^{2}\right)$ at a cell temperature of $25^{\circ} \mathrm{C}$ (IEC 60904-3: 2008, ASTM G-173-03 global) [18, 20]

\begin{tabular}{|c|c|c|c|c|c|c|c|}
\hline \multirow{2}{*}{ Classification $^{1)}$} & Eff & $S^{2)}$ & Voc & Jsc & $F F$ & \multirow{2}{*}{$\begin{array}{c}\text { Test centre }^{3)} \\
\text { (data) }\end{array}$} & \multirow{2}{*}{ Description } \\
\hline & {$[\%]$} & {$\left[\mathrm{cm}^{2}\right]$} & {$[\mathbf{V}]$} & {$\left[\mathbf{m A} / \mathbf{c m}^{2}\right]$} & {$[\%]$} & & \\
\hline Si (crystalline) & $22.9 \pm 0.6$ & $778(\mathrm{da})$ & 5.60 & 3.97 & 80.3 & \begin{tabular}{|l|} 
Sandia $(9 / 96)$ \\
\end{tabular} & UNSW/Gochermann \\
\hline Si (large crystalline) & $22.4 \pm 0.6$ & $\begin{array}{c}15775 \\
\text { (ap) }\end{array}$ & 69.57 & 6.341 & 80.1 & $\operatorname{NREL}(8 / 12)$ & SunPower \\
\hline $\mathrm{Si}$ (multicrystalline) & $18.5 \pm 0.4$ & $\begin{array}{c}14661 \\
\text { (ap) }\end{array}$ & 38.97 & 9.149 & 76.2 & $\begin{array}{c}\text { FhG-ISE } \\
(1 / 12)\end{array}$ & $\begin{array}{c}\text { Q-Cells } \\
\text { (60 serial cells) }\end{array}$ \\
\hline $\begin{array}{c}\text { Si (thin film } \\
\text { polycrystalline) }\end{array}$ & $8.2 \pm 0.2$ & $\begin{array}{l}661 \\
\text { (ap) }\end{array}$ & 25.0 & 0.320 & 68.0 & Sandia $(7 / 02)$ & $\begin{array}{c}\text { Pacific Solar } \\
(<2 \mathrm{~m} \text { on glass })\end{array}$ \\
\hline GaAs (thin film) & $24.1 \pm 1.0$ & $\begin{array}{l}858.5 \\
\text { (ap) } \\
\end{array}$ & 10.89 & 2.255 & 84.2 & $\begin{array}{l}\text { NREL } \\
(11 / 12) \\
\end{array}$ & Alta Devices \\
\hline CdTe (thin film) & $17.5 \pm 0.7$ & $\begin{array}{l}7021 \\
\text { (ap) }\end{array}$ & 103.1 & 1.553 & 76.6 & $\operatorname{NREL}(2 / 14)$ & First Solar (monolithic) \\
\hline CIGS (thin film)) & $15.7 \pm 0.5$ & $\begin{array}{l}9703 \\
(\mathrm{ap})\end{array}$ & 28.24 & 7.254 & 72.5 & $\begin{array}{l}\text { NREL } \\
(11 / 10)\end{array}$ & Miasole \\
\hline CIGSS (Cd free) & $13.5 \pm 0.7$ & $\begin{array}{l}3459 \\
\text { (ap) }\end{array}$ & 31.2 & 2.18 & 68.9 & NREL (8/02) & Showa Shell \\
\hline CIGS (Cd free) & $17.5 \pm 0.5$ & $\begin{array}{l}808 \\
\text { (da) }\end{array}$ & 47.6 & 0.408 & 72.8 & AIST (6/14) & $\begin{array}{l}\text { Solar Frontier } \\
(70 \text { cells })\end{array}$ \\
\hline a-Si/nc-Si (tandem) & $11.6 \pm 0.5$ & $\begin{array}{c}14250 \\
(\mathrm{t})\end{array}$ & 198.5 & 1.254 & 66.2 & $\operatorname{ESTI}(12 / 13)$ & $\begin{array}{c}\text { TEL Solar, } \\
\text { Trubbach Labs }\end{array}$ \\
\hline a-Si/nc-Si (tandem) & $12.2 \pm 0.3$ & $\begin{array}{l}14322 \\
\text { (t) }\end{array}$ & 202.1 & 1.261 & 68.8 & ESTI (6/14) & $\begin{array}{c}\text { TEL Solar, } \\
\text { Trubbach Labs }\end{array}$ \\
\hline Organic & $8.7 \pm 0.3$ & $\begin{array}{l}802 \\
\text { (da) }\end{array}$ & 17.47 & 0.569 & 70.4 & AIST (5/14) & Toshiba \\
\hline
\end{tabular}

1) CIGSS - CuInGaSSe, a-Si - amorphous silicon/hydrogen alloy, a-SiGe - amorphous silicon/germanium/ hydrogen alloy, nc-Si - nanocrystalline or microcrystalline silicon

2) t - total area, ap - aperture area, da - designated illumination area

3) AIST - Japanese National Institute of Advanced Industrial Science and Technology, NREL - National Renewable Energy Laboratory, FhG-ISE - Fraunhofer Institut für Solare Energiesysteme, ESTI - European Solar Test Installation

Table 5

'Notable Exceptions': 'Top ten' confirmed cell and module results, not class records measured under the global AM1.5 spectrum $\left(1000 \mathrm{~W} / \mathrm{m}^{2}\right)$ at $25^{\circ} \mathrm{C}$ (IEC 60904-3: 2008, ASTM G-173-03 global) [18, 20]

\begin{tabular}{|c|c|c|c|c|c|c|c|}
\hline \multirow{2}{*}{ Classification $^{1)}$} & $E f f$ & $S^{2)}$ & Voc & Jsc & $F F$ & \multirow{2}{*}{$\begin{array}{l}\text { Test centre }^{3)} \\
\text { (data) }\end{array}$} & \multirow{2}{*}{ Description $^{4)}$} \\
\hline & {$[\%]$} & {$\left[\mathrm{cm}^{2}\right]$} & [V] & {$\left[\mathbf{m A} / \mathbf{c m}^{2}\right]$} & {$[\%]$} & & \\
\hline \multicolumn{8}{|c|}{ Cells (silicon) } \\
\hline $\mathrm{Si}$ (crystalline) & $25.0 \pm 0.5$ & $4.00(\mathrm{da})$ & 0.706 & 42.7 & 82.8 & Sandia (3/99) & $\begin{array}{l}\text { UNSW PERL } \\
\text { top/rear contacts }\end{array}$ \\
\hline $\begin{array}{c}\text { Si (large } \\
\text { crystalline) }\end{array}$ & $25.0 \pm 0.7$ & $\begin{array}{c}120.94 \\
(\mathrm{t})\end{array}$ & 0.726 & 41.5 & 82.8 & FhG-ISE (2/14) & $\begin{array}{c}\text { SunPower } \\
\text { rear junction }\end{array}$ \\
\hline $\begin{array}{c}\mathrm{Si} \text { (large } \\
\text { multicrystalline) }\end{array}$ & $19.5 \pm 0.4$ & $242.7(\mathrm{t})$ & 0.652 & 39.0 & 76.7 & FhG-ISE (3/11) & $\begin{array}{c}\text { Q-Cells, } \\
\text { laser-fired contacts }\end{array}$ \\
\hline \multicolumn{8}{|c|}{ Cells (III-V) } \\
\hline GaInP & $20.8 \pm 0.6$ & $\begin{array}{c}0.2491 \\
\text { (ap) }\end{array}$ & 1.4550 & 16.04 & 89.3 & NREL (5/13) & $\begin{array}{c}\text { NREL, } \\
\text { high bandgap }\end{array}$ \\
\hline \multicolumn{8}{|c|}{ Cells (chalcogenide) } \\
\hline CIGSS (Cd free) & $20.9 \pm 0.7$ & $\begin{array}{c}0.5192 \\
\text { (ap) }\end{array}$ & 0.6858 & 39.91 & 76.4 & FhG-ISE (3/14) & $\begin{array}{c}\text { Showa Shell } \\
\text { on glass }\end{array}$ \\
\hline CIGS (thin film) & $21.7 \pm 0.7$ & $\begin{array}{c}0.4972 \\
\text { (da) }\end{array}$ & 0.7963 & 36.59 & 79.3 & FhG-ISE (9/14) & $\begin{array}{c}\text { ZSW } \\
\text { on glass }\end{array}$ \\
\hline
\end{tabular}




\begin{tabular}{|c|c|c|c|c|c|c|c|}
\hline \multirow{2}{*}{ Classification $^{1)}$} & $E f f$ & $S^{2)}$ & Voc & $J s c$ & $F F$ & \multirow{2}{*}{$\begin{array}{l}\text { Test centre }{ }^{3)} \\
\text { (data) }\end{array}$} & \multirow{2}{*}{ Description $^{4)}$} \\
\hline & [\%] & {$\left[\mathrm{cm}^{2}\right]$} & {$[\mathbf{V}]$} & {$\left[\mathrm{mA} / \mathrm{cm}^{2}\right]$} & {$[\%]$} & & \\
\hline $\begin{array}{l}\text { CIGSS (Cd free } \\
\text { module) }\end{array}$ & $16.6 \pm 0.8$ & $\begin{array}{c}660.3 \\
\text { (ap) }\end{array}$ & 26.7 & 0.895 & 69.5 & NREL (1/14) & Avancis (monolithic) \\
\hline CdTe (thin film) & $20.4 \pm 0.5$ & $\begin{array}{l}0.4778 \\
\text { (da) }\end{array}$ & 0.8717 & 29.47 & 79.5 & Newport $(12 / 13)$ & First Solar on glass \\
\hline CZTSS (thin film) & $12.6 \pm 0.3$ & $\begin{array}{l}0.4209 \\
\text { (ap) }\end{array}$ & 0.5134 & 35.21 & 69.8 & Newport (7/13) & IBM solution grown \\
\hline CZTS (thin film) & $8.5 \pm 0.2$ & $\begin{array}{c}0.2382 \\
\text { (da) }\end{array}$ & 0.708 & 16.83 & 70.9 & AIST (1/13) & $\begin{array}{c}\text { Toyota Central R\&D } \\
\text { Labs }\end{array}$ \\
\hline \multicolumn{8}{|c|}{ Cells (other) } \\
\hline $\begin{array}{l}\begin{array}{l}\text { Perovskite } \\
\text { (thin film) }\end{array} \\
\end{array}$ & $17.9 \pm 0.8$ & $\begin{array}{l}0.0937 \\
\text { (ap) } \\
\end{array}$ & 1.1142 & 21.8 & 73.6 & Newport (4/14) & KRICT \\
\hline $\begin{array}{l}\text { Perovskite } \\
\text { (thin film) }\end{array}$ & $20.1 \pm 0.4$ & $\begin{array}{l}0.0955 \\
\text { (ap) }\end{array}$ & 1.059 & 24.65 & 77.0 & $\begin{array}{l}\text { Newport } \\
(11 / 14)\end{array}$ & KRICT \\
\hline $\begin{array}{l}\text { Organic } \\
\text { (thin film) }\end{array}$ & $11.1 \pm 0.3$ & $\begin{array}{l}0.159 \\
\text { (ap) }\end{array}$ & 0.867 & 17.81 & 72.2 & AIST (10/12) & Mitsubishi Chemical \\
\hline
\end{tabular}

1) CIGSS, CuInGaSSe, CZTSS, $\mathrm{Cu}_{2} \mathrm{ZnSnS}_{4-\mathrm{y}} \mathrm{Se}_{\mathrm{y}}, \mathrm{CZTS}, \mathrm{Cu}_{2} \mathrm{ZnSnS}_{4}$

2) $\mathrm{t}$ - total area, ap - aperture area, da - designated illumination area

3) AIST - Japanese National Institute of Advanced Industrial Science and Technology, NREL - National Renewable Energy Laboratory, FhG-ISE - Fraunhofer Institut für Solare Energiesysteme, ESTI - European Solar Test Installation

4) KRICT - Korean Research Institute of Chemical Technology

Terrestrial concentrator cell and module efficiencies measured under the ASTM G-173-03 direct beam AM1.5 spectrum at a cell temperature of $25^{\circ} \mathrm{C}[18,20]$

\begin{tabular}{|c|c|c|c|c|c|}
\hline \multirow{2}{*}{ Classification $^{1)}$} & Eff & $S^{1)}$ & Intensity $^{2)}$ & \multirow{2}{*}{$\begin{array}{l}\text { Test centre }{ }^{3)} \\
\text { (data) }\end{array}$} & \multirow{2}{*}{ Description $^{3)}$} \\
\hline & {$[\%]$} & {$\left[\mathrm{cm}^{2}\right]$} & [suns] & & \\
\hline \multicolumn{6}{|c|}{ Single cells } \\
\hline GaAs & $29.1 \pm 1.3$ & 0.0505 (da) & 117 & FhG-ISE (3/10) & Fraunhofer ISE \\
\hline $\mathrm{Si}$ & $27.6 \pm 1.2$ & $1.00(\mathrm{da})$ & 92 & FhG-ISE (11/04) & Amonix back-contact \\
\hline CIGS (thin film) & $23.3 \pm 1.2$ & 0.09902 (ap) & 15 & NREL (3/14) & NREL \\
\hline \multicolumn{6}{|c|}{ Multijunction cells } \\
\hline InGaP/GaAs/InGaAs & $44.4 \pm 2.6$ & $0.1652(\mathrm{da})$ & 302 & FHG-ISE (4/13) & $\begin{array}{c}\text { Sharp } \\
\text { inverted metamorphic }\end{array}$ \\
\hline $\begin{array}{c}\text { GaInP/GaAs; } \\
\text { GaInAsP/GaInAs }\end{array}$ & $46.0 \pm 2.2$ & 0.0520 (da) & 508 & AIST (10/14) & $\begin{array}{c}\text { Soitec/CEA/FhG-ISE } \\
\text { bonded }\end{array}$ \\
\hline \multicolumn{6}{|c|}{ Submodule } \\
\hline $\begin{array}{c}\text { GaInP/GaAs; } \\
\text { GaInAsP/GaInAs }\end{array}$ & $38.5 \pm 1.9$ & 0.202 (ap) & 20 & NREL (8/08) & $\begin{array}{l}\text { DuPont et al., } \\
\text { split spectrum }\end{array}$ \\
\hline GaInP/GaInAs/Ge; $\mathbf{S i}$ & $40.4 \pm 2.8$ & 287 (ap) & 365 & NREL (11/14) & UNSW split spectrum \\
\hline \multicolumn{6}{|c|}{ Modules } \\
\hline $\mathrm{Si}$ & $20.5 \pm 0.8$ & 1875 (ap) & 79 & Sandia (4/89) & $\begin{array}{c}\text { Sandia/UNSW/ENTECH } \\
\text { (12 cells) }\end{array}$ \\
\hline Triple junction & $35.9 \pm 1.8$ & 1092 (ap) & N/A & NREL (8/13) & Amonix \\
\hline Four junction & $36.7 \pm 2.6$ & 829.6 (ap) & N/A & FhG-ISE (5/14) & Fraunhofer ISE \\
\hline \multicolumn{6}{|c|}{ 'Notable exceptions' } \\
\hline Si (large area) & $21.7 \pm 0.7$ & $20.0(\mathrm{da})$ & 11 & Sandia $(9 / 90)$ & UNSW laser grooved \\
\hline Luminescent submodule & $7.1 \pm 0.2$ & 25 (ap) & 2.5 & ESTI $(9 / 08)$ & ECN Petten, GaAs cells \\
\hline
\end{tabular}

1) t - total area, ap - aperture area, da - designated illumination area

2) One sun corresponds to direct irradiance of $1000 \mathrm{~W} / \mathrm{m}^{2}$

3) ESTI - European Solar Test Installation 
Summary of world records with date of the notice by the testing laboratory and a short parameters and characteristics of the technology on which they are made, are shown in Tables 3-6. In Table 3 efficiencies (measured in STC conditions) of solar cells and PV minimodules for terrestrial applications were collected, in Table 4 - modules. In Table 5 the top ten best results obtained by cells and modules were shown, and in Table 6 the efficiencies of solar cells and modules for ground-based applications with the concentration of solar radiation were collected. It is worth noting that for the cells with absorber made of crystal InP, best result has not been beaten since 1990. While the efficiencies of the cells: the dye sensitized cells, organic and based on perovskites rapidly increased.

\section{Future of photovoltaics}

To use the full potential of solar energy we should increase the efficiency of PV cells (Fig. 17). Now we have steady and stable increase in PV cells efficiency, but most of these new cells are not commercially available. Actual records of efficiency are held by cells with concentrators (actual 46\% cell from Soltec, 4-junction, 508 times concentrated light). This technology is only profitable for big photovoltaic power plants that can use lens or mirrors and also use cooling devices. For small PV systems we still use silicon solar cells and they efficiency increase is very limited. But if we take into consideration not only technical efficiency, but also cost of modules, we can observe decrease of prices per $\mathrm{W}_{\mathrm{p}}$ (Fig. 18). This price drop causes that PV modules are much more accessible and profitable in an increasingly larger parts of the world.

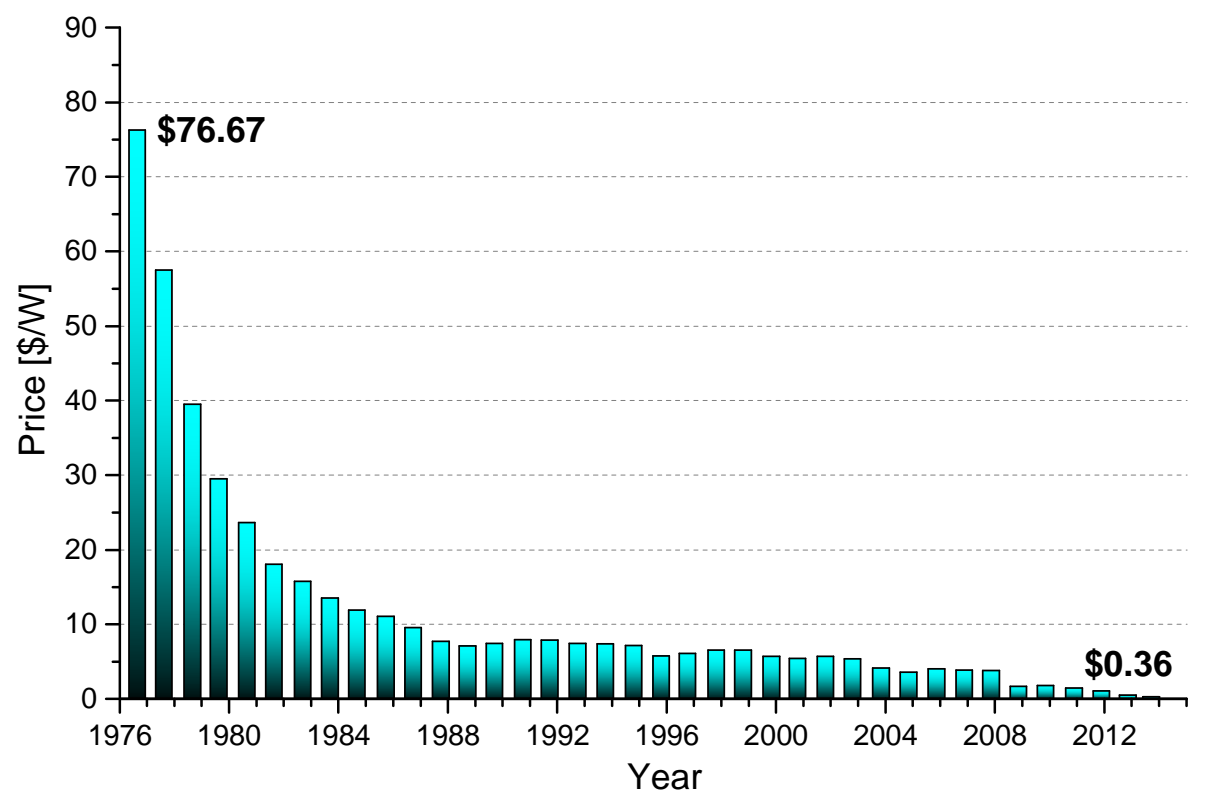

Fig. 18. Price history chart of crystalline silicon solar cells in \$ per watt since 1977 [21]

Predictions for PV market in EU made by EPIA (European Photovoltaic Industry Association) are very optimistic (Fig. 19). We can see stable increase of installed power in 
all scenarios (high, medium and low). Also in historical data can be observed growth even in years of economic crisis (2008-2010). Of course low prices of standard energy carriers that we have nowadays can reduce the price competitiveness of solar cells, but in the longer term photovoltaics should be very important source of energy.

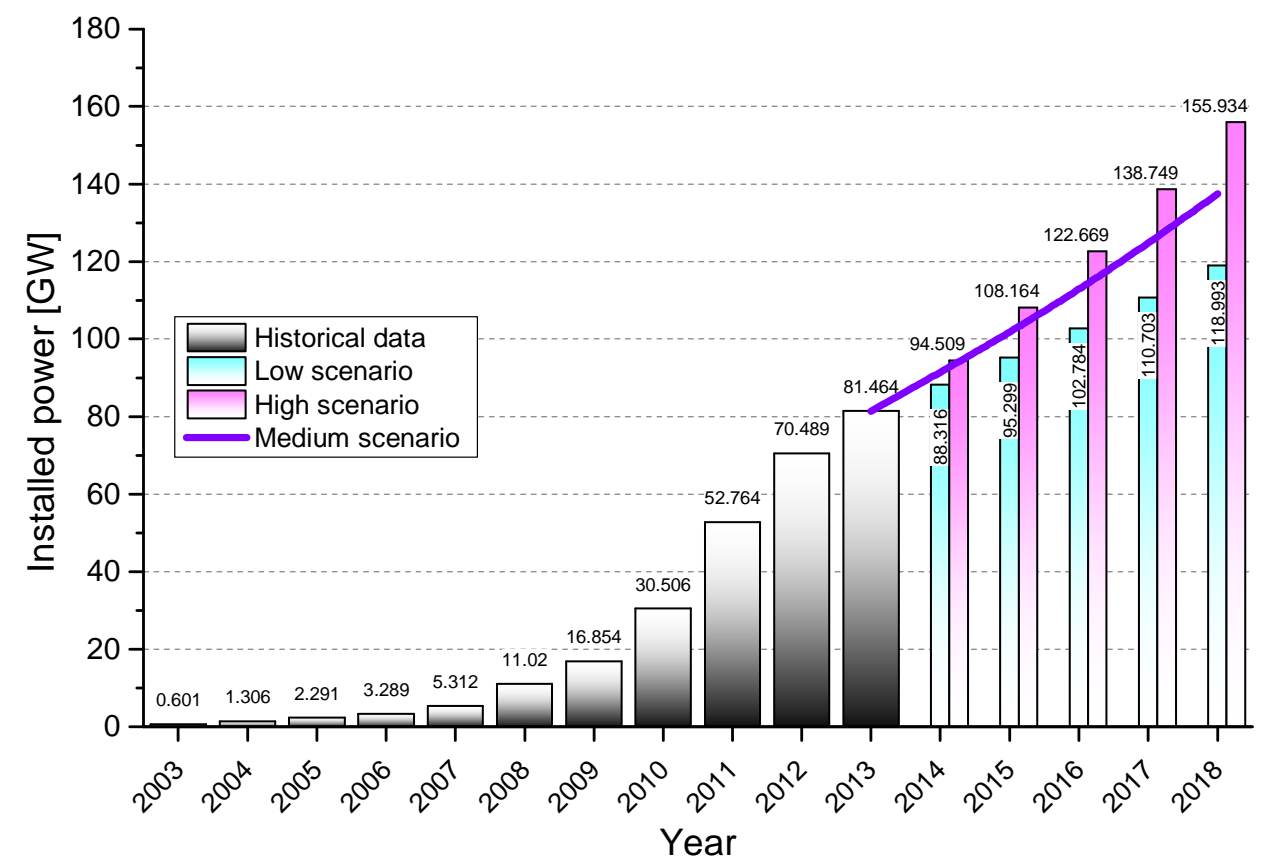

Fig. 19. Scenarios for European PV market [22]

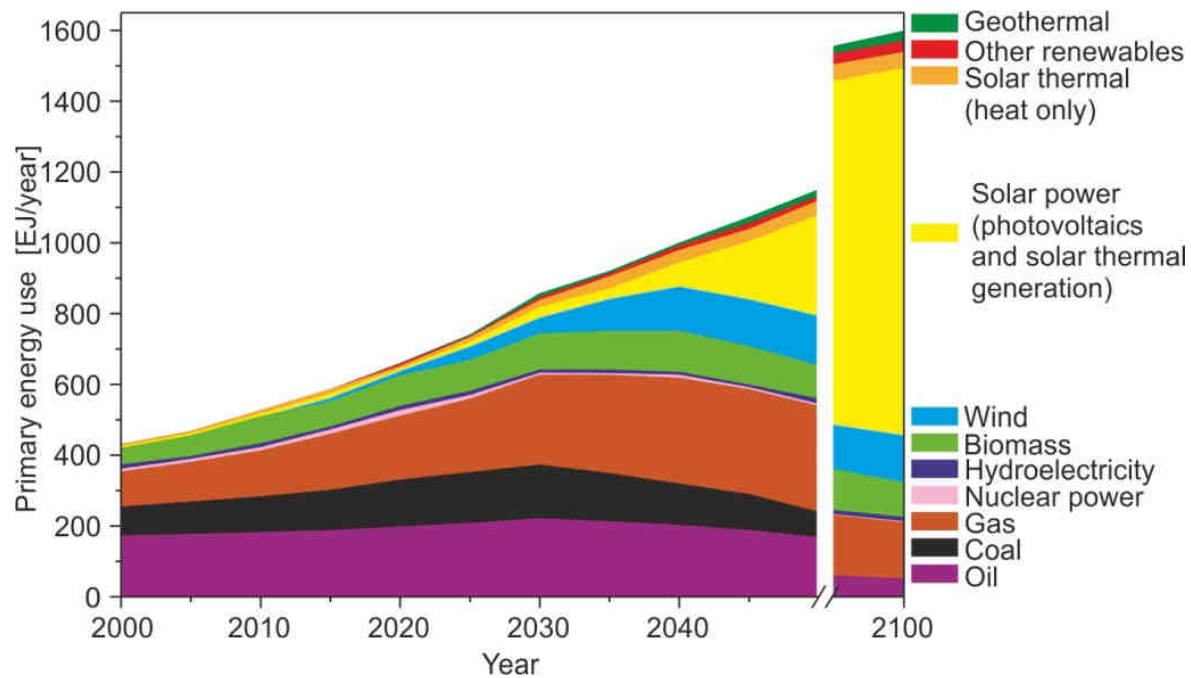

Fig. 20. Prediction of primary energy use [23] 
Also long-term prognoses prepared by German Advisory Council on Global Change (WBGU) are very good for solar energy (not only photovoltaics, but also solar thermal generation, for example solar towers). It shows that solar energy can be the most important source of energy in the near future (90 years - Fig. 20).

\section{Photovoltaics power plants}

For production of big amount of energy the most important are photovoltaics power plants. The biggest have power over 0.5 GW (Topaz Solar Farm [24] and Desert Sunlight Solar Farm [25] in USA - $550 \mathrm{MW}_{\mathrm{p}}$ ) and can produce over $1 \mathrm{GWh}$ energy per year. But not only USA invest in photovoltaic power plant, plants with power more than $100 \mathrm{MW}$ have many countries (China, Germany, India, France, Ukraine (on Crimea) and Chile). PV power plants show that photovoltaics is very flexible technology. PV systems can be adapted to the needs of customers and their power can start from few watts even to GW and more. Their size is only matter of needs and of course possible to use surface.

Especially power plants in Germany (rather standard climatic conditions for Europe) gives hope that PV power plants can be used not only in sunny climate, but also in whole Europe.

Photovoltaic plants have also competition: solar towers using mirror to concentrate solar radiation to increase temperature of fluids (often molten salts) and these fluids change water to steam and it feeds a turbine. But this technology is not so safe and flexible as photovoltaics, it fits only for big power plants and also causes problems, because concentrated sunlight can kills animals and birds, has traditional steam turbine and generators that make noise. So solar towers can be only used in distant area (plants over $100 \mathrm{MW}$ are only in Spain and USA).

\section{Energy storage}

Main problem in use of photovoltaics and wider in all renewable energy sources are the seasonal and daily changes in energy production. Even though the development of renewable energy resources analysis, not only photovoltaics [4], but also in other types of Renewable Energy Sources [8], seasonality of this energy production is a big problem.

This problem causes that energy storage is very important and it should be resolved in a cheap and cost-effective way. Also we need long-term (days or weeks) storage of energy that helps us to avoid periods with smaller energy production. Today's methods for storage energy that can be used to cover high energy demands are: pumped water (change of electrical energy to potential energy of water), CAES (Compressed Air Energy Storage), advanced lead acid batteries and new flow batteries. Flow batteries are new type of chemical energy storage in which electrolyte is pumped, so battery better uses it and have higher power density. But these systems have limited power density (they have high energy but can't fast produce high power). It seems that the greatest potential have a hybrid system (supercapacitors and different type of batteries, fuel cells and hydrogen storage, flywheel and water pumps, etc.)

\section{Conclusions}

1. Solar energy is the most environmental friendly energy source, so it can be used everywhere, also this type RES is the most accepted technology. 
2. The increase in efficiency and decrease in cost are making photovoltaics cost-effective for growing area.

3. Limits of use for photovoltaics are connected with daily and seasonal changes of energy production and can be solved by energy storages.

4. The problem of electricity storage is not resolved in a cheap, effective way and yet does not allow us to long-term storage of this energy.

5. Increasing the percentage of renewable energy sources, enforces energy storage use.

\section{References}

[1] Encyklopedia PWN - Fakty i liczby. (PWN Encyclopedia - Facts and Figures). Warszawa: Wyd Nauk PWN; 2006.

[2] http://www.greenpeace.org/international/en/publications/reports/Solar-Generation-2010/.

[3] Wacławek M, Rodziewicz T. Ogniwa słoneczne. Wpływ środowiska naturalnego na ich pracę. (Solar cells. Influence of environment on their performance). II edition. Warszawa: WNT; 2015.

[4] Rodziewicz T, Teneta J, Zaremba A, Wacławek M. Analysis of solar energy resources in Southern Poland for photovoltaic applications. Ecol Chem Eng S. 2013;20(1):177-198. DOI: 10.2478/eces-2013-0014.

[5] Żdanowicz T, Rodziewicz T, Wacławek M. Theoretical analysis of the optimum energy band gap of semiconductors for fabrication of solar cells for applications in higher latitudes location. Solar Energy Mater Solar Cells. 2005;87:757-769. DOI:10.1016/j.solmat.2004.07.049.

[6] IEC 61853 (draft 82/254): Performance testing and energy rating of terrestrial photovoltaic (PV) modules. http://www.iec.ch/dyn/www/f?p=103:23:0::::FSP_ORG_ID:1276.

[7] IEC 61724: Photovoltaic System Performance Monitoring - Guidelines for Measurement, Data Exchange and Analysis. https://webstore.iec.ch/preview/info_iec61724\%7Bed1.0\%7Den.pdf.

[8] Blaesser G, Munro D. Guidelines for the Assessment of Photovoltaic Plants. Analysis and Presentation of Monitoring Data. Luxembourg: ECSC-EC-EAEC; 1993. http://bookshop.europa.eu/en/guidelines-for-theassessment-of-photovoltaic-plants-pbCLNA16339/downloads/CL-NA-16-339-ENC/CLNA16339ENC_001.pdf;pgid=Iq1Ekni0.11SR0OOK4MycO9B0000Sk2p11dZ;sid=9CUbbL5A83MbfjU93OFy9x18_Ydv7mT8vY=?FileName=CLNA16339ENC_001.pdf\&SKU=CLNA16339ENC_PDF\&Catal ogueNumber=CL-NA-16-339-EN-C.

[9] Technical documentation of Sunny Boy 1100 inverter. http://files.sma.de/d1/5668/SB1100E-11-EE5000.pdf.

[10] Popławski T, Szeląg P, Głowiński C, Adamowicz Ł. Forecast of Electric Power Generated by the Wind Farm Using Data Clustering Method. In: Information Systems Architecture and Technology. Knowledge Based Approach to the Design, Control and Decision Support. Wrocław: Ofic Wyd Politechniki Wrocławskiej; 2013; 175-184.

[11] Page J, Albuisson M, Wald L. The European solar radiation atlas: a valuable digital tool. Solar En. 2001;71:81-83. DOI: 10.1016/S0038-092X(00)00157-2.

[12] Suri M, Dunlop ED, Jones AR, Hofierka J. GIS-Based Inventory of the Potential Photovoltaic Output in Central and Eastern Europe. Proc 18th Eur Photovolt Solar En Conf Exhibition Sci, Technol Application. Rome: 2002. https://www.researchgate.net/publication/237332062_gis-based_inventory_of_the_potential_ photovoltaic_output_in_central_and_eastern_europe.

[13] Kasten F, Young A. Revised optical air mass tables and approximation formula. Appl Optics. 1989;28:4735-8. DOI: 10.1364/AO.28.004735.

[14] Palz W. The European Solar Radiation Atlas. Köln, Commission of the European Communities 1984.

[15] Liu B, Jordan R. The interrelationship and characteristic distribution of direct, diffuse and total radiation. Solar En. 1960;4:1-19. DOI: 10.1016/0038-092X(60)90062-1.

[16] Osterwald CR, Emery KA, Myers DR, Riordan CJ. Extending the Spectral Range of Silicon-Based DirectBeam Solar Spectral Radiometric Measurements. Conf Record Twentieth IEEE Photovolt Specialists Conf. 1988. DOI: 10.1109/PVSC.1988.105904.

[17] http://www.nrel.gov/ncpv/images/efficiency_chart.jpg.

[18] Green MA, Emery K, Hishikawa Y, Warta W, Dunlop ED. Solar cell efficiency tables (version 44). Prog Photovolt: Res Appl. 2014;22:701-710. DOI: 10.1002/pip.2525.

[19] NREL press release NR-4514, 16 December 2014.

[20] Green MA, Emery K, Hishikawa Y, Warta W, Dunlop ED. Solar cell efficiency tables (version 45). Prog Photovolt: Res Appl. 2015;23:1-9. DOI: 10.1002/pip.2573.

[21] Hanjin, Rfassbind [Public domain], Wikimedia Commons. http://commons.wikimedia.org/wiki/ File:Price_history_of_silicon_PV_cells_since_1977.svg. 
[22] Global market outlook. For photovoltaics 2014-2018. EPIA. 2014. http://www.epia.org/uploads/ tx_epiapublications/44_epia_gmo_report_ver_17_mr.pdf.

[23] World in Transition. Towards Sustainable Energy Systems. German Advisory Council on Global Change (WBGU). 2004.http://www.wbgu.de/fileadmin/templates/dateien/veroeffentlichungen/ hauptgutachten/jg2003/wbgu_jg2003_engl.pdf.

[24] http://www.renewableenergyworld.com/rea/news/article/2011/12/billionaire-buffett-bets-on-solar-energy? cmpid=SolarNL-Thursday-December8-2011.

[25] http://www.firstsolar.com/en/about-us/projects/desert-sunlight-solar-farm. 